\title{
Porezni klin u Hrvatskoj, Sloveniji, Češkoj Republici, Portugalu i Francuskoj
}

Beketić, Ivana

Source / Izvornik: Odabrani prijevodi, 2016, 7, 1 - 29

Journal article, Published version

Rad u časopisu, Objavljena verzija rada (izdavačev PDF)

https://doi.org/10.3326/op.38

Permanent link / Trajna poveznica: https:/urn.nsk.hr/urn:nbn:hr:242:836296

Rights / Prava: Attribution-NonCommercial-NoDerivatives 4.0 International/ImenovanjeNekomercijalno-Bez prerada 4.0 međunarodna

Download date / Datum preuzimanja: 2023-04-26

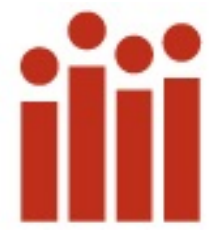

Repository / Repozitorij:

Institute of Public Finance Repository

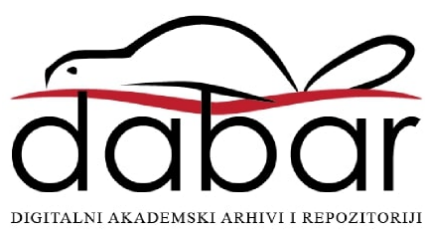


Institut za

javne financije

Smičiklasova 21 | Zagreb

www.ijf.hr | ured@ijf.hr

T: 01/4886-444 | F: 01/4819-365

ODABRANI

PRIJEVODI

\section{BR. 38}

\section{6.}

ISSN 1847-7445

\section{Porezni klin u HRVATSKoJ, SloveniJi, ČešKoJ Republici, Portugalu i FrancuskoJ}

MAG. MATH IVANA BEKETIĆ ${ }^{*}$

\author{
PRETHODNO PRIOPĆENJE** \\ JEL: H21, H24, J38 \\ DOI: $10.3326 /$ op.38
}

\section{SAŽETAK}

Cilj ovog rada je usporediti prosječno porezno opterećenje dohotka od rada u Hrvatskoj, Češkoj Republici, Francuskoj, Portugalu i Sloveniji. Korištenjem OECD-ove Taxing Wages metodologije napravljena je usporedba poreznog klina za osam tipova hipotetskih pojedinaca i obitelji. Hrvatska ima najniži porezni klin u svim slučajevima. Francuska se pokazala kao zemlja s najvišim poreznim klinom za sve tipove samaca i obitelji.

Ključne riječi: oporezivanje dohotka od rada, neto prosječna porezna stopa, porezni klin, Hrvatska, Češka Republika, Francuska, Portugal, Slovenija

* Autorica zahvaljuje anonimnim recenzentima na njihovim korisnim komentarima i prijedlozima. Ovaj članak je dio posebnog izdanja časopisa Financial Theory and Practice, posvećenom usporedbi poreznog klina na dohodak od rada u Hrvatskoj i drugim zemljama EU-a. Članci u tom izdanju su nastali na temelju studentskog istraživačkog projekta poduzetog 2015. Predgovor posebnom izdanju (Urban, 2016.) opisuje motivaciju istraživačkog projekta, objašnjava najvažnija metodološka pitanja te pruža pregled literature o mjerenju poreznog klina u Hrvatskoj.

Stavovi izneseni u ovom radu su isključivo stavovi autorice i ne odražavaju stavove institucija u kojoj je zaposlena.

${ }^{* *}$ Primljeno: 29. siječnja 2016.

Prihvaćeno: 4. travnja 2016.

\section{Ivana BEKETIĆ}

UNIQA osiguranje d.d., Planinska 13a, 10000 Zagreb

e-mail: ivana.beketic@gmail.com 


\section{UvoD}

U ovom radu uspoređuje se porezno opterećenje dohotka od rada u odabranim zemljama EU-a, a to su Hrvatska, Češka Republika, Francuska, Portugal i Slovenija. ${ }^{1}$ Za svaku zemlju izračunavaju se iznosi doprinosa za socijalno osiguranje, poreza na dohodak i novčanih naknada za obitelj, za osam hipotetskih tipova pojedinaca i obitelji. Zatim se uspoređuju neto prosječni porezni klin i neto prosječna porezna stopa, kako bi se uočile razlike u poreznom opterećenju između zemalja za različite hipotetske jedinice.

Metodologija istraživanja je zasnovana na OECD-ovoj publikaciji Taxing Wages (OECD, 2014.). Iz spomenute publikacije preuzeti su podaci o obilježjima oporezivanja dohotka u zemljama OECD-a: primjeni olakšica i stopa u sustavu poreza na dohodak, o stopama doprinosa za socijalno osiguranje, te novčanim obiteljskim naknadama. Također su iz OECD-a (2014.) preuzete vrijednosti pokazatelja poreznog opterećenja. Podaci o sustavu oporezivanja dohotka od rada za Hrvatsku prikupljeni su pregledom postojećih zakona, a pokazatelji poreznog opterećenja izračunati su uz pomoć autoričinog mikrosimulacijskog modela za hipotetske jedinice.

Rad je organiziran na sljedeći način. U drugom dijelu govori se o metodologiji rada. U trećem dijelu slijedi pregled po zemljama, koji sadrži detaljan opis sustava oporezivanja dohotka od rada i novčanih obiteljskih naknada, te izračune i analizu pokazatelja poreznog opterećenja za hipotetske jedinice. U četvrtom dijelu nalazi se usporedba pokazatelja poreznog opterećenja za sve zemlje. Peti dio predstavlja zaključak.

\section{Metodologija: MOdel I POKAZATElJI}

Analiza zemalja temelji se na podacima iz 2013. objavljenim u publikaciji Taxing Wages (OECD, 2014.), gdje su detaljno prikazane informacije vezane za oporezivanje plaća u zemljama članicama OECD-a. Kako bi se konačni rezultati različitih zemalja mogli međusobno usporediti, ista metodologija se mora koristiti i pri izračunima pokazatelja za Hrvatsku, koja nije članica OECD-a. Pokazatelji poreznog opterećenja izračunavaju se za osam hipotetskih jedinica (Tablica 1). Promatraju se samci i parovi, pri čemu svaka od tih hipotetskih jedinica može biti bez djece ili imati dvoje djece. Kod obitelji s djecom, prema OECD-ovoj metodologiji, pretpostavlja se da ona imaju između šest i jedanaest godina. Analiza poreznog opterećenja rada počiva na pretpostavci da porezni obveznik dohodak ostvaruje isključivo od nesamostalnog rada, i to na temelju plaće, dok su ostali izvori dohotka isključeni iz razmatranja. ${ }^{2} U$ svakoj obitelji je barem jedna odrasla osoba zaposlena na puno radno vrijeme. Pretpostavlja se da radnici nisu koristili bolovanje te da nisu bili nezaposleni u nekom razdoblju promatrane godine.

Sukladno Taxing Wages metodologiji (OECD, 2014.), "prosječna bruto plaća” (average gross wage; AGW) obuhvaća određene sektore gospodarstva. Kako bi izračuni bili u skladu s metodologijom OECD-a, AGW za Hrvatsku dobiva se kao ponderirana prosječna bruto plaća u sektorima od B do N, pri čemu su ponderi prosječni brojevi posloprimaca u svakom pojedinom sektoru. ${ }^{3}$ Tako se za

\footnotetext{
${ }^{1}$ Ovaj članak je dio tematskog broja časopisa. Uvodni članak (Urban, 2016.) govori o motivaciji istraživanja te sadrži pregled literature o usporedbama poreznog klina u Hrvatskoj i ostalim zemljama.

2 Postoje i druge vrste dohodaka na koje se plaća porez na dohodak, npr. dohodak od samostalne djelatnosti, imovine, kapitala i osiguranja.

${ }^{3}$ Za detalje izračuna AGW-a u ostalim zemljama, vidjeti OECD (2014.). U Hrvatskoj se primjenjuje Nacionalna kvalifikacija djelatnosti (DZS, 2013.), koja je usklađena s "NACE Rev. 2" klasifikacijom.
} 
Hrvatsku u 2013. dobiva AGW u iznosu od 7.765 kune. Usporedbe radi, prosječna bruto plaća za 2013. u svim sektorima iznosila je 7.929 kuna (DZS, 2015.).

\section{TABLICA 1.}

Obilježja hipotetskih jedinica

\begin{tabular}{lcccc}
$\begin{array}{l}\text { Oznaka u } \\
\text { ovom radu }\end{array}$ & Odrasli članovi & Broj djece & $\begin{array}{c}\text { Supružnik I } \\
\text { (\% AGW-a) }\end{array}$ & $\begin{array}{c}\text { Supružnik II } \\
\text { (\% AGW-a) }\end{array}$ \\
\hline 1A-67-NC & samac & 0 & $2 / 3 \times 100$ & - \\
\hline 1A-100-NC & samac & 0 & 100 & - \\
\hline 1A-167-NC & samac & 0 & $5 / 3 \times 100$ & - \\
\hline 1A-67-2C & samac & 2 & $2 / 3 \times 100$ & ne radi \\
\hline $2 \mathrm{~A}-100 / 0-2 \mathrm{C}$ & par & 2 & 100 & $1 / 3 \times 100$ \\
\hline $2 \mathrm{~A}-100 / 33-2 \mathrm{C}$ & par & 2 & 100 & $2 / 3 \times 100$ \\
\hline $2 \mathrm{~A}-100 / 67-2 \mathrm{C}$ & par & 2 & 100 & $1 / 3 \times 100$ \\
\hline $2 \mathrm{~A}-100 / 33-\mathrm{NC}$ & par & 0 & 100 & - \\
\hline
\end{tabular}

Napomena: Kratice su zasnovane na engleskom jeziku. Značenje pojedinih simbola je sljedeće: AGW - average gross wage (prosječna bruto plaća), sukladno Taxing Wages metodologiji; $A$ - adult (odrasla osoba); $N C$ - no children (bez djece); $2 C$ 2 children (dvoje djece).

Izvor: OECD (2014).

\section{TABLICA 2.}

Godišnje prosječne bruto plaće u odabranim zemljama, 2013.

\begin{tabular}{lccc} 
& AGW (u nacionalnoj valuti) & Tečaj & AGW (u eurima) \\
\hline Hrvatska & HRK 93.180 & HRK/EUR $=7,5735$ & 12.303 \\
\hline Češka Rep. & CZK 298.770 & CZK/EUR $=26,0824$ & 11.455 \\
\hline Francuska & EUR 36.980 & 1 & 36.980 \\
\hline Portugal & EUR 17.335 & 1 & 17.335 \\
\hline Slovenija & EUR 17.611 & 1 & 17.611 \\
\hline
\end{tabular}

Izvor: (1) AGW - za Hrvatsku: autoričin izračun prema DZS (2015.); za ostale zemlje: OECD (2014.); (2) tečajevi - za Hrvatsku: prosječni godišnji tečaj kune prema euru (HNB, 2016.); za Češku Republiku: OECD (2014.).

Tablica 2 prikazuje AGW u promatranim zemljama na godišnjoj razinu i u eurima. Važno je napomenuti da u slučaju hipotetske jedinice 2A-100/33-NC jedan supružnik ima bruto plaću od 33\% AGW-a, što iznosi 2.620 kuna. Za Hrvatsku je taj niži od minimalne plaće (Zakon o minimalnoj plaći) koja je 2013. iznosila 2.988 kuna. Međutim, kako bi se poštivala Taxing Wages metodologija, u izračunima se za spomenutog supružnika upotrebljava iznos od 33\% AGW-a.

Kako objašnjava Urban (2016.), ukupni trošak rada je zbroj bruto plaće, doprinosa poslodavca i poreza na platnu listu. Ukupni neto porez je zbroj svih doprinosa, poreza na platnu listu i poreza na dohodak, umanjen za novčane naknade za obitelj. Neto porez posloprimca je zbroj doprinosa posloprimca i poreza na dohodak umanjen za novčane naknade za obitelj. Neto prosječni porezni klin je omjer između ukupnog neto poreza i ukupnog troška rada. Neto prosječna porezna stopa je omjer između neto poreza posloprimca i bruto plaće.

Važno je naglasiti da se pod doprinose posloprimca i poslodavca uzimaju u obzir samo doprinosi koji se plaćaju općoj državi, dok su doprinosi uplaćeni u fondove izvan opće države isključeni iz analize. Primjerice, u Hrvatskoj postoje dva stupa mirovinskog osiguranja - prvi i drugi stup. Doprinosi posloprimca u prvi stup su prihodi opće države, a doprinosi za drugi stup su prihodi 
obveznih privatnih fondova. Stoga će prvi ući u izračun pokazatelja poreznog opterećenja, a drugi neće. O ovoj temi opširnije vidjeti u Urban (2016.), Blažić i Trošelj (2012.), OECD (2014., 2015.).

\section{OPOREZIVANJE DOHOTKA U ODABRANIM ZEMLJAMA}

\subsection{HRVATSKA}

\subsubsection{OSNOVNI ELEMENTI OPOREZIVANJA DOHOTKA OD RADA U HRVATSKOJ 2013.}

U Hrvatskoj posloprimac od iznosa svoje bruto plaće odvaja ukupno $20 \%$ za doprinose, od čega $15 \%$ za mirovinsko osiguranje na temelju generacijske solidarnosti (tzv. prvi stup) i $5 \%$ za mirovinsko osiguranje na temelju individualne kapitalizirane štednje (tzv. drugi stup) (Tablica 3).

\section{TABLICA 3.}

Stope doprinosa posloprimca (Hrvatska, 2013.)

\begin{tabular}{lc} 
Doprinos & Stopa (\%) \\
\hline Za prvi stup mirovinskog osiguranja & 15 \\
\hline Za drugi stup mirovinskog osiguranja & 5 \\
\hline Ukupno & 20
\end{tabular}

Izvor: Zakon o doprinosima (NN 84/08., 152/08., 94/09., 18/11., 22/12., 144/12., 148/13., 41/14.).

Doprinosi poslodavca sastoje se od doprinosa za zdravstveno osiguranje po stopi od $13 \%$, za zapošljavanje 1,7\% i 0,5\% za zdravstveno osiguranje zaštite zdravlja na radu (Tablica 4).

\section{TABLICA 4.}

Stope doprinosa poslodavca (Hrvatska, 2013.)

Doprinos Stopa (\%)

\begin{tabular}{lr} 
Zapošljavanje & 1,7 \\
\hline Zdravstveno osiguranje & 13,0 \\
\hline Zdravstveno osiguranje zaštite zdravlja na radu & 0,5 \\
\hline Ukupno & 15,2
\end{tabular}

Izvor: Zakon o doprinosima (NN 84/08., 152/08., 94/09., 18/11., 22/12., 144/12., 148/13., 41/14.).

Prema podacima Porezne uprave (MFRH-PU, 2015.), u 2013. godišnji osobni odbitak u sustavu poreza na dohodak iznosio je 3.486 eura (26.400 kuna). Kod poreznog obveznika s djecom, osobni odbitak se uvećava za faktor 0,5 za prvo dijete, 0,7 za drugo dijete, faktor 1 za treće dijete i za svako sljedeće dijete faktor se progresivno povećava u odnosu na faktor osobnog odbitka za prethodno dijete. Pritom se djetetom smatra svako uzdržavano dijete sve do završetka školovanja, odnosno dok se ne zaposli. Uzdržavanim članom se smatra član uže obitelji čija godišnja primanja ne prelaze 1.452 eura i u tom slučaju faktor na osobni odbitak iznosi 0,5 . U slučaju invalidnosti dodatni faktor iznosi 0,3 , odnosno kod $100 \%$ invalidnosti faktor je 1 (ova dva slučaja su međusobno isključiva, odnosno ne mogu se oba faktora primjenjivati). Iznos osobnog odbitka je veći kod potpomognutih područja, grada Vukovara i u slučaju umirovljenika.

Osnovica poreza na dohodak računa se tako da se od iznosa bruto plaće oduzmu doprinosi posloprimca i iznos osobnog odbitka (zajedno s odbitcima za djecu i uzdržavane članove). Ako je dohodak (razlika bruto plaće i doprinosa posloprimca) manji od osobnog odbitka, porezna 
osnovica je jednaka nuli i u tom slučaju osoba ne plaća porez. Postoje tri porezna razreda, sa stopama od 12\%, 25\% i 40\% (tablica 5).

\section{TABLICA 5.}

Razredi i stope poreza na dohodak (Hrvatska, 2013.)

Porezna osnovica (EUR)

\begin{tabular}{ll}
\hline$<3.486$ & 12 \\
\hline $3.486-13.943$ & 25 \\
\hline$>13.943$ & 40
\end{tabular}

Izvor: Zakon o porezu na dohodak (NN 177/04., 73/08., 80/10., 114/11., 22/12., 144/12., 43/13., 120/13., 125/13., 148/13., 83/14., 143/14.).

U Hrvatskoj postoji i prirez, koji se obračunava na iznos poreza na dohodak po stopi koja ovisi o mjestu prebivališta poreznog obveznika. Stopa prireza može biti od $0 \%$ do $18 \%$. U slučaju općine prirez iznosi do $10 \%$, za grad do 30.000 stanovnika iznosi do $12 \%$, za grad iznad 30.000 stanovnika iznosi do $15 \%$. Za Grad Zagreb stopa prireza je 18\%, to je ujedno i trenutno najviša stopa prireza u primjeni u Hrvatskoj. U izračunima se koristi prirez od 12\%.

U Hrvatskoj se mjesečno isplaćuje doplatak za djecu čiji iznos ovisi o visini ukupnog neto dohotka i broju članova kućanstva. Prema Zakonu o doplatku za djecu dohotkom se smatra dohodak od: nesamostalnog rada (plaća), samostalne djelatnosti, imovine i imovinskih prava, kapitala, osiguranja i drugi primitci (poput mirovina iz inozemstva, naknade za nezaposlenost i slično). Doplatak se isplaćuje za uzdržavano dijete do 15. godine ako pohađa osnovnu školu, odnosno do 19. godine, ako pohađa srednju školu. U slučaju djece s težim oštećenjima zdravlja dohodak se isplaćuje do 27. godine (moguće i dulje uz naknadna vještačenja). "Proračunska osnovica" na temelju koje se računa iznos doplatka za djecu u 2013. je iznosila 3.326 kuna (439 eura). Pritom postoje tri cenzusne skupine. Prvu skupinu čine kućanstva čiji prosječni mjesečni dohodak po članu kućanstva ne prelazi 16,3\% proračunske osnovice i mjesečni doplatak za djecu tada iznosi $9 \%$ proračunske osnovice po djetetu (299 kuna; 40 eura). Drugu skupinu čine kućanstva čiji je prosječni mjesečni dohodak po članu kućanstva između 16,3\% i 33,7\% proračunske osnovice i tada doplatak za djecu iznosi 7,5\% proračunske osnovice po djetetu (250 kuna; 33 eura). Treću skupinu čine kućanstva čiji je prosječni mjesečni dohodak po članu kućanstva između 33,7\% i 50\% proračunske osnovice, u kojoj doplatak za djecu iznosi $6 \%$ proračunske osnovice za svako dijete (200 kuna; 26 eura). Za dijete bez oba roditelja ili čiji su roditelji nesposobni za samostalan život, iznos doplatka za djecu se povećava za $25 \%$, odnosno za $15 \%$ za dijete s jednim roditeljem. Djeca s oštećenjima zdravlja ostvaraju pravo na doplatak uvećan za $25 \%$. U slučaju težih oštećenja zdravlja djeteta, doplatak za djecu iznosi $25 \%$ proračunske osnovice bez obzira na visinu prihoda kućanstva. Kućanstvu s tri djeteta naknada se uvećava za tzv. "pronatalitetni dodatak" u iznosu od 500 kuna mjesečno (66 eura). "Pronatalitetni dodatak” iznosi 1.000 kuna (132 eura) mjesečno za kućanstva s četiri ili više djece.

Od osam analiziranih hipotetskih jedinica dvije primaju doplatak za djecu. Kako hipotetska obitelj 1A-67-2C ima mjesečni dohodak od 4.234 kuna, ostvaruje pravo na doplatak za djecu iz treće cenzusne skupine. Budući da je odrasla osoba samohrani roditelj, doplatak se uvećava za $15 \%$ i on iznosi 459 kuna (61 euro) mjesečno. Kod hipotetske obitelji 2A-100/0-2C jedan supružnik prima plaću od 100\% AGW-a, a drugi je nezaposlen. Ovdje se također radi o trećoj cenzusnoj skupini 
(dohodak po članu obitelj iznosi oko 1.588 kuna) i mjesečni doplatak za dvoje djece iznosi 400 kuna (53 eura). Kod ostalih parova s dvoje djece mjesečni dohodak po članu obitelji prelazi 50\% iznosa proračunske osnovice (1.663 kune), pa se ne ostvaruje pravo na doplatak za djecu.

\subsubsection{NETO PROSJEČNA POREZNA STOPA I NETO PROSJEČNI POREZNI KLIN U HRVATSKOJ}

Progresivnost sustava za samce bez djece provjerava se usporedbom neto prosječne porezne stope i neto prosječnog poreznog klina za jedinice 1A-67-NC, 1A-100-NC i 1A-167-NC, koje imaju različite razine bruto plaće. Progresivnost sustava također se ispituje za parove s dvoje djece, usporedbom neto prosječne porezne stope i neto prosječnog poreznog klina, za jedinice 2A-100/0-2C, 2A100/33-2C i 2A-100/67-2C, kod kojih se razlikuje bruto plaća drugog supružnika.

Utjecaj poreznih olakšica i naknada za djecu analizira se usporedbom hipotetskih jedinica: (a) za samce - 1A-67-NC i 1A-67-2C, i (b) za parove - 2A-100/33-NC i 2A-100/33-2C. Jedinice 1A-67-NC i 1A-67-2C (2A-100/33-NC i 2A-100/33-2C) su jednake s obzirom na obilježja odraslih članova, ali se razlikuju po broju djece.

Grafikon 1 prikazuje neto prosječnu poreznu stopu i neto prosječni porezni klin za osam hipotetskih jedinica u Hrvatskoj. Detaljne izračune prikazuju tablice A1 i A2 u dodatku. Bitno je napomenuti da doprinosi za drugi stup mirovinskog osiguranja ne ulaze u izračun pokazatelja poreznog opterećenja (sukladno metodologiji OECD-a, 2014.; također vidjeti objašnjenje u Urban, 2016.).

Za samce bez djece sustav je progresivan jer neto prosječna porezna stopa i neto prosječni porezni klin rastu s bruto plaćom. Neto prosječni porezni klin kod 1A-167-NC je za 9 postotnih bodova veći nego kod 1A-67-NC. Za parove s dvoje djece sustav je također progresivan. Neto prosječni porezni klin kod 2A-100/0-2C je za 7 postotnih bodova veći nego kod 2A-100/67-2C.

\section{GRAFIKON 1.}

Neto prosječni porezni klin i neto prosječna porezna stopa za hipotetske jedinice (Hrvatska, 2013.), u \%

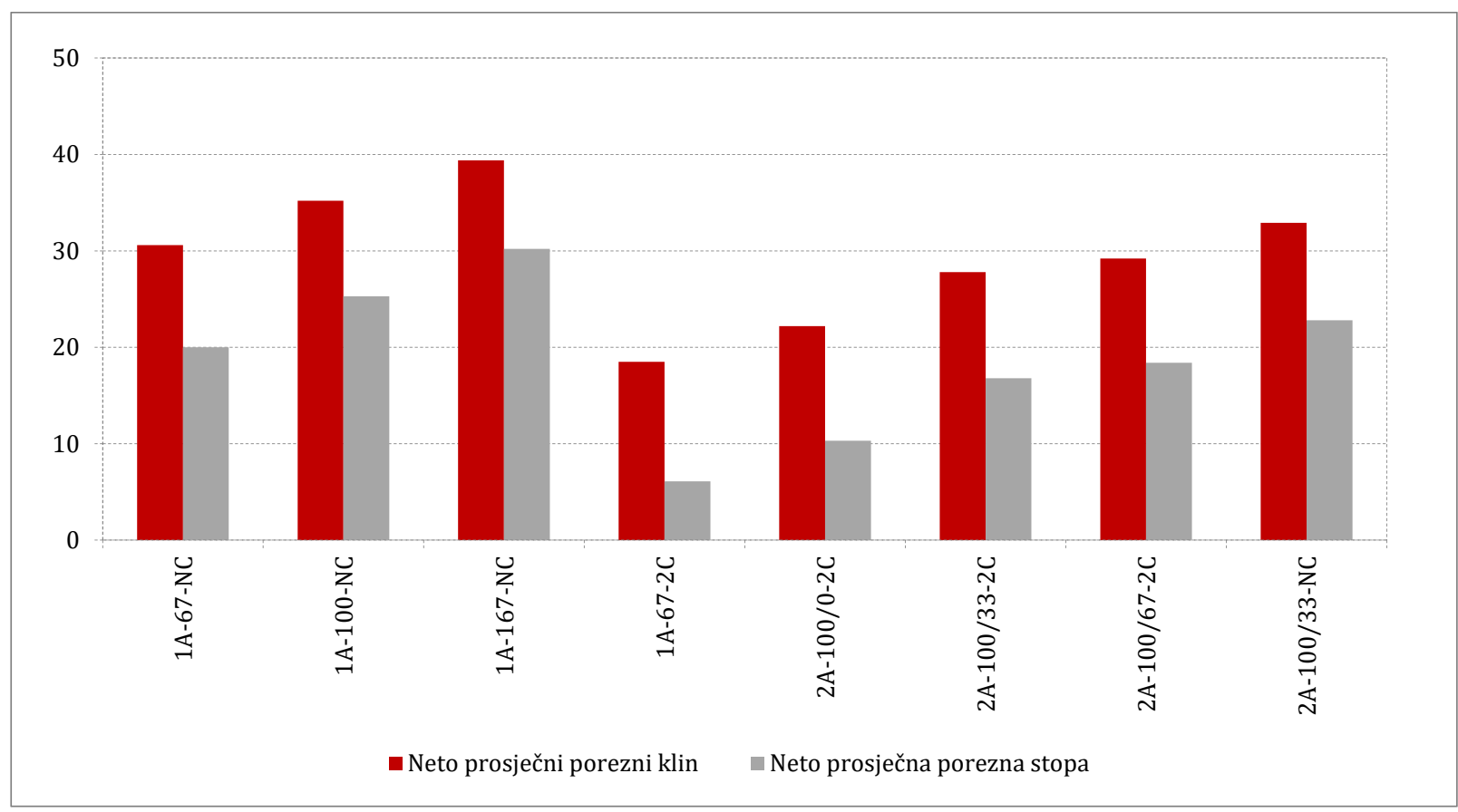

Izvor: autoričin izračun. 
Neto prosječni porezni klin kod jedinice $1 \mathrm{~A}-67-2 \mathrm{C}$ niži je 12 postotnih bodova nego za jedinicu $1 \mathrm{~A}-$ 67-NC. Porezni klin kod jedinice 2A-100/33-2C niži je 5 postotnih bodova nego za jedinicu 2A100/33-NC.

\section{2. ČEŠKA REPUBLIKA}

\subsubsection{OSNOVNI ELEMENTI OPOREZIVANJA RADA U ČEŠKOJ REPUBLICI 2013.}

U Češkoj Republici posloprimci iz bruto plaće izdvajaju 4,5\% za zdravstveno osiguranje i 6,5\% za socijalno osiguranje (Tablica 6). Od 2012. najviša osnovica za plaćanje doprinosa iznosi 47.635 eura na godišnjoj razini.

\section{TABLICA 6.}

Stope doprinosa posloprimca (Češka Republika, 2013.)

\begin{tabular}{lc} 
Doprinos & Stopa (\%) \\
\hline Zdravstveno osiguranje & 4,5 \\
\hline Socijalno osiguranje & 6,5 \\
\hline Ukupno & 11,0
\end{tabular}

Izvor: OECD (2014.).

Doprinosi poslodavca iznose ukupno 34\% bruto plaće, a sastoje se od zdravstvenog osiguranja $(9 \%)$ i socijalnog osiguranja (25\%) (Tablica 7).

\section{TABLICA 7.}

Stope doprinosa poslodavca (Češka Republika, 2013.)

\begin{tabular}{lc} 
Doprinos & Stopa (\%) \\
\hline Zdravstveno osiguranje & 9 \\
\hline Socijalno osiguranje & 25 \\
\hline Ukupno & 34
\end{tabular}

Izvor: OECD (2014.).

U Češkoj Republici obveznik poreza na dohodak je pojedinac. Za donacije općinama, te za donacije za socijalne, zdravstvene, crkvene i sportske aktivnosti u iznosu od barem $2 \%$ iznosa porezne osnovice, porezni odbitak iznosi 10\% iznosa porezne osnovice (OECD, 2014.). Porezni obveznici mogu podnijeti zahtjev za odbitak u iznosu od 11.502 eura za troškove kamata po stambenom kreditu, odnosno za troškove po osnovi kamata zbog kupnje ili uređenja stambenog prostora. Osobe koje plaćaju dopunsko mirovinsko osiguranje imaju pravo na odbitak u visini stvarnih uplata na godišnjoj razini, umanjeno za 230 eura, pri čemu je maksimalan iznos olakšice 460 eura. Svaki porezni obveznik ostvaruje pravo na umanjenje poreza (tax credit) u iznosu od 952 eura. Obveznik ima pravo na dodatno umanjenje poreza u iznosu od 952 eura u slučaju kada supružnik koji s njim prebiva ne ostvari godišnja primanja viša od 2.607 eura. Ako obveznik ima djecu mlađu od 18 godina, odnosno mlađu od 26 godina, koja se redovno školuju ili djecu s posebnim potrebama mlađu od 26 godina, tada ima pravo na 514 eura umanjenja poreza. Dodatna umanjenja poreza vezana za osobe s posebnim potrebama iznose 97 eura (djelomična invalidnost), odnosno 193 eura za potpunu invalidnost te 619 eura za osobe s posebnim potrebama kojima treba posebna njega 
(dodatna osoba). Ukoliko se obveznik i dalje školuje, do 26., odnosno 28. godine, ima pravo na dodatno umanjenje poreza od 154 eura.

Porezna osnovica u Češkoj Republici se računa tako da se od ukupnog zbroja iznosa bruto plaće, socijalnih naknada uključenih u poreznu osnovicu i doprinosa poslodavca oduzme iznos poreznih odbitaka. Od 2008. postoji jedinstvena porezna stopa od 15\% koja se primjenjuje na poreznu osnovicu (Kalíšková et al., 2014.).

Novčana naknada za obitelj se dodjeljuje obiteljima koje ispunjavaju dohodovnu provjeru. Dohodovni cenzus ovisi o broju i obilježjima članova kućanstva; za detalje izračuna iznosa naknade vidjeti OECD (2014.) i Kalíšková et al. (2014.).

\subsubsection{PROSJEČNE POREZNE STOPE I POREZNI KLIN U ČEŠKOJ REPUBLICI}

Grafikon 2 prikazuje neto prosječnu poreznu stopu i neto prosječni porezni klin za osam hipotetskih jedinica u Češkoj Republici. Detaljne izračune prikazuju tablice A3 i A4 u dodatku.

Za samce bez djece sustav je progresivan jer neto prosječna porezna stopa i neto prosječni porezni klin rastu s bruto plaćom. Neto prosječni porezni klin kod 1A-167-NC je za 6 postotnih bodova veći nego kod 1A-67-NC. Za parove s dvoje djece sustav je također progresivan. Neto prosječni porezni klin kod 2A-100/0-2C je za 11 postotnih bodova veći nego kod 2A-100/67-2C.

Neto prosječni porezni klin kod jedinice 1A-67-2C niži je 25 postotnih bodova nego za jedinicu $1 \mathrm{~A}-$ 67-NC. Porezni klin kod jedinice 2A-100/33-2C niži je 5 postotnih bodova nego za jedinicu 2A100/33-NC.

GRAFIKON 2.

Neto prosječni porezni klin i neto prosječna porezna stopa za hipotetske jedinice (Češka R., 2013.), u \%

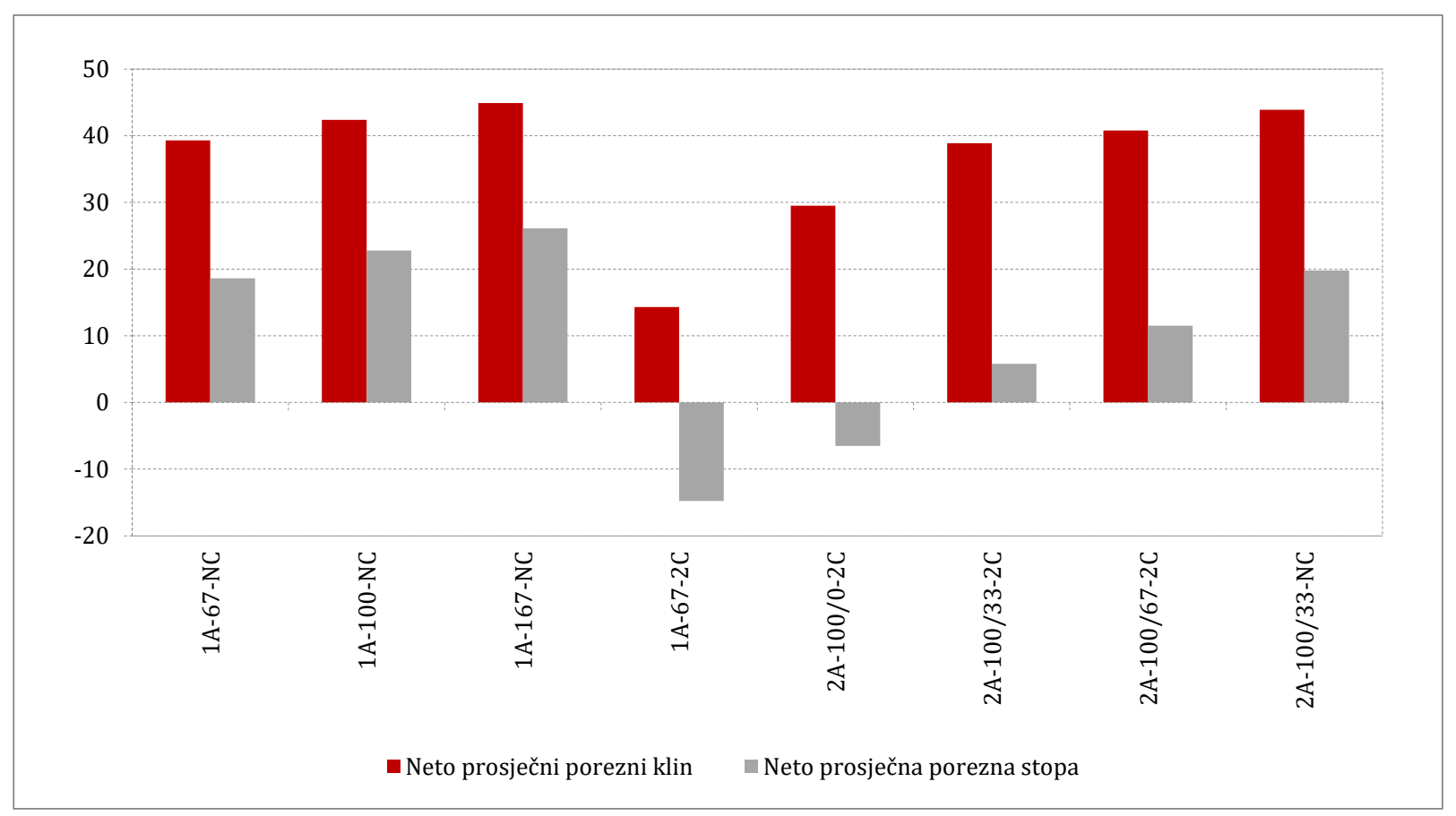

Izvor: autoričini izračuni na temelju OECD-a (2014.). 


\subsection{Francuska}

\subsubsection{OSNOVNI ELEMENTI OPOREZIVANJA DOHOTKA OD RADA U FRANCUSKOJ 2013.}

Za mirovinsko osiguranje posloprimci u Francuskoj iz bruto plaće izdvajaju 0,1\% od iznosa cijele bruto plaće i 6,75\% na iznos bruto plaće do maksimalne vrijednosti od 3.086 eura (mjesečno) (tablica 8). Za zdravstveno osiguranje izdvaja se 0,75\% iznosa ukupne bruto plaće. Doprinosi za osiguranje za nezaposlenost iznose $2,4 \%$ i obračunavaju se na bruto plaću do maksimalnog iznosa 12.344 eura (referentna vrijednost pomnožena sa 4). Ostali doprinosi uključuju dodatno mirovinsko osiguranje od 3\% iznosa bruto plaće do referentne vrijednosti i 8\% od bruto plaće do maksimalnog iznosa 9.258 eura (referentna vrijednost pomnožena s 3), odnosno u slučaju menadžera, 3\% iznosa bruto plaće do referentne vrijednosti i 7,7\% od bruto plaće do maksimalnog iznosa 12.344 eura (referentna vrijednost pomnožena s 4). Association pour la gestion du fonds de financement (AGFF) je doprinos sličan mirovinskom osiguranju, a iznosi $0,8 \%$ bruto plaće do iznosa referentne vrijednosti i $0,9 \%$ iznosa bruto plaće do trostrukog iznosa maksimalne vrijednosti.

\section{TABLICA 8.}

Stope doprinosa posloprimca (Francuska, 2013.)

\begin{tabular}{lc} 
Doprinos & Stopa (\%) \\
\hline Mirovinsko osiguranje & 6,85 \\
\hline Zdravstveno osiguranje & 0,75 \\
\hline Osiguranje za nezaposlenost & 2,4 \\
\hline Ostalo & različite stope
\end{tabular}

Izvor: OECD (2014.).

U Francuskoj poslodavci izdvajaju $10 \%$ bruto plaće za mirovinsko osiguranje posloprimaca, pri čemu se 1,6\% primjenjuje bez gornje granice, dok se za preostalih $8,4 \%$ primjenjuje gornja granica od 3.086 eura (Tablica 9). Doprinos za zdravstveno osiguranje iznosi 12,8\% od iznosa ukupne bruto plaće, a za nezaposlenost se izdvaja 4\% iznosa bruto plaće s maksimumom od 12.344 eura (referentna vrijednost pomnožena sa 4). Doprinosi za osiguranje u slučaju nezgode na radu variraju, a prosječna stopa doprinosa za 2013. je iznosila 2,43\% na iznos ukupne bruto plaće. I na kraju, za obiteljske doprinose poslodavci izdvajaju 5,4\% od iznosa bruto plaće. U ostale doprinose ulaze dodatno mirovinsko osiguranje od 4,5\% iznosa bruto plaće do referentne vrijednosti i $12 \%$ za bruto plaće između 3.086 i 9.258 eura. U slučaju menadžera te stope iznose redom 4,5\% i 12,6\%. Za AGFF se plaća doprinos od 1,2\% bruto plaće do maksimalnog iznosa 3.086 eura i 1,2\%, odnosno $1,3 \%$ za menadžere od iznosa bruto plaće u iznosu između 3.086 i 9.258 eura. Za poduzeća s 20 ili više zaposlenih plaća se dodatnih 3,23\% doprinosa na iznos bruto plaće.

\section{TABLICA 9.}

Stope doprinosa poslodavca (Francuska, 2013.)

\begin{tabular}{lc} 
Doprinos & Stopa (\%) \\
\hline Mirovinsko osiguranje & 10,00 \\
\hline Zdravstveno osiguranje & 12,80 \\
\hline Osiguranje za nezaposlene & 4,00 \\
\hline Osiguranje od nezgode na radu & 2,43 \\
\hline Obiteljski doprinosi & 5,40 \\
\hline Ostalo & različite stope \\
\hline
\end{tabular}


Prema OECD-u (2014.), u standardne olakšice poreza na dohodak pripadaju troškovi vezani za rad i troškovi za uzdržavanu djecu. Ako djeca idu u školu, dodatne olakšice iznose 61, 153 ili 183 eura, ovisno o stupnju školovanja. Dodatne olakšice uključuju iznose za uređenje doma (veća kapitalna ulaganja poput toplinske izolacije ili opremanje doma za proizvodnju energije iz obnovljivih izvora), zatim troškove razvoda, troškove uzdržavanja djece do sedam godina, donacije za razne udruge i slično. Prime pour l'emploi (PPE) je individualizirano umanjenje poreza koji ovisi o iznosu bruto plaće, poreznoj osnovici i broju radnih sati. Kako bi porezni obveznik ostvario pravo na PPE, bruto primanja kućanstva trebaju biti do 16.251 eura za samca, 25.231 eura za samohranog roditelja s dvoje djece, 32.498 eura za parove bez djece te 41.478 eura za parove s dvoje djece. Iznos može biti uvećan za 36 eura za svako uzdržavano dijete ili u slučaju samohranog roditelja koji zarađuje plaću.

Prema Avram i Bouvard (2014.), u Francuskoj postoji posebna metoda oporezivanja dohotka, foyer fiscal, prema kojoj se oporezuju prihodi jednog poreznog obveznika zajedno s osobama koje fiskalno ovise o njemu. Djeca ispod 18 godina i djeca s posebnim potrebama (bez obzira na godine) automatski se smatraju uzdržavanim članovima obitelji. Također, uzdržavanim članovima se mogu smatrati i djeca mlađa od 21 godinu, odnosno ona u dobi do 25 godina ako su upisana na studij visokog obrazovanja. Primjenjuje se sistem obiteljskog omjera (eng. family quotient system), pri čemu se u obzir uzima bračni status i status, odnosno pozicija u obitelji. Svakoj osobi u obitelji se daje određeni faktor, odnosno porezni obveznik, njegov supružnik i treće (i svako sljedeće dijete) imaju faktor 1 , dok prvo i drugo dijete imaju faktor 0,5 . U posebnim slučajevima se pridodaju faktori, a to su: udovica/udovac s barem jednim uzdržavanim djetetom (faktor 1), odrasla osoba ili dijete s posebnim potrebama (faktor 0,5 ) i samohrani roditelj (faktor 0,5 ). Obiteljski omjer je zbroj svih faktora koji vrijede za osobe u određenoj poreznoj skupini. ${ }^{4}$ Iznos neto oporezivih primanja dobiva se tako da se od iznosa bruto primanja oduzmu gore navedeni odbici i olakšice te se doda iznos socijalnih naknada uključenih u poreznu osnovicu. Na kraju, kako bi se dobila poreznu osnovicu, iznos ukupnih neto oporezivih primanja porezne skupine dijeli se s obiteljskim omjerom. Ako je iznos poreza ispod 1.016 eura, porez se dodatno smanjuje za polovinu razlike 1.016 eura i poreza prije ovog smanjenja. Na dijelove porezne osnovice primjenjuju se porezne stope koje prikazuje Tablica 10.

\section{TABLICA 10.}

Razredi i stope poreza na dohodak (Francuska, 2013.)

\begin{tabular}{lc} 
Porezna osnovica (EUR) & Stopa (\%) \\
\hline$<6.011$ & 0 \\
\hline $6.011-11.991$ & 5,5 \\
\hline $11.991-26.631$ & 14 \\
\hline $26.631-71.397$ & 30 \\
\hline $71.397-15.1200$ & 41 \\
\hline$>15.1200$ & 45 \\
\hline
\end{tabular}

Izvor: OECD (2014.).

${ }_{4}^{4}$ Primjerice, par s dvoje djece ima faktor 3 (1 za poreznog obveznika +1 zbog supružnika $+0,5$ za prvo dijete $+0,5$ za drugo dijete). 
U Francuskoj postoje lokalni prirezi, čije stope variraju ovisno o pokrajini, ali u OECD-u (2014.) oni nisu uzeti u razmatranje, pa se tako čini i u ovom radu.

Prema Avram i Bouvard (2014.) godišnje naknade za obitelj, iznose 360 eura za dijete u dobi od 6 do 10 godina, 380 eura za dijete u dobi od 11 do 14 godina, odnosno 394 eura za dijete do 18 godina. Dodatno se obiteljima s troje ili više djece isplaćuje mjesečna naknada od 167 eura.

\subsubsection{NETO PROSJEČNA POREZNA STOPA I NETO PROSJEČNI POREZNI KLIN U FRANCUSKOJ}

Grafikon 3 prikazuje neto prosječnu poreznu stopu i neto prosječni porezni klin za osam hipotetskih jedinica u Francuskoj. Detaljne izračune prikazuju tablice A5 i A6 u dodatku.

Za samce bez djece sustav je progresivan jer neto prosječna porezna stopa i neto prosječni porezni klin rastu s bruto plaćom. Neto prosječni porezni klin kod 1A-167-NC je za 9 postotnih bodova veći nego kod 1A-67-NC. Za parove s dvoje djece sustav je također progresivan, ali znatno blaže nego za samce. Neto prosječni porezni klin kod $2 \mathrm{~A}-100 / 0-2 \mathrm{C}$ je za 3 postotna boda veći nego kod 2A100/67-2C.

Neto prosječni porezni klin kod jedinice 1A-67-2C niži je 8 postotnih bodova nego za jedinicu 1A67-NC. Porezni klin kod jedinice 2A-100/33-2C niži je 5 postotnih bodova nego za jedinicu 2A100/33-NC.

\section{GRAFIKON 3.}

Neto prosječni porezni klin i neto prosječna porezna stopa za hipotetske jedinice (Francuska, 2013.), $u \%$

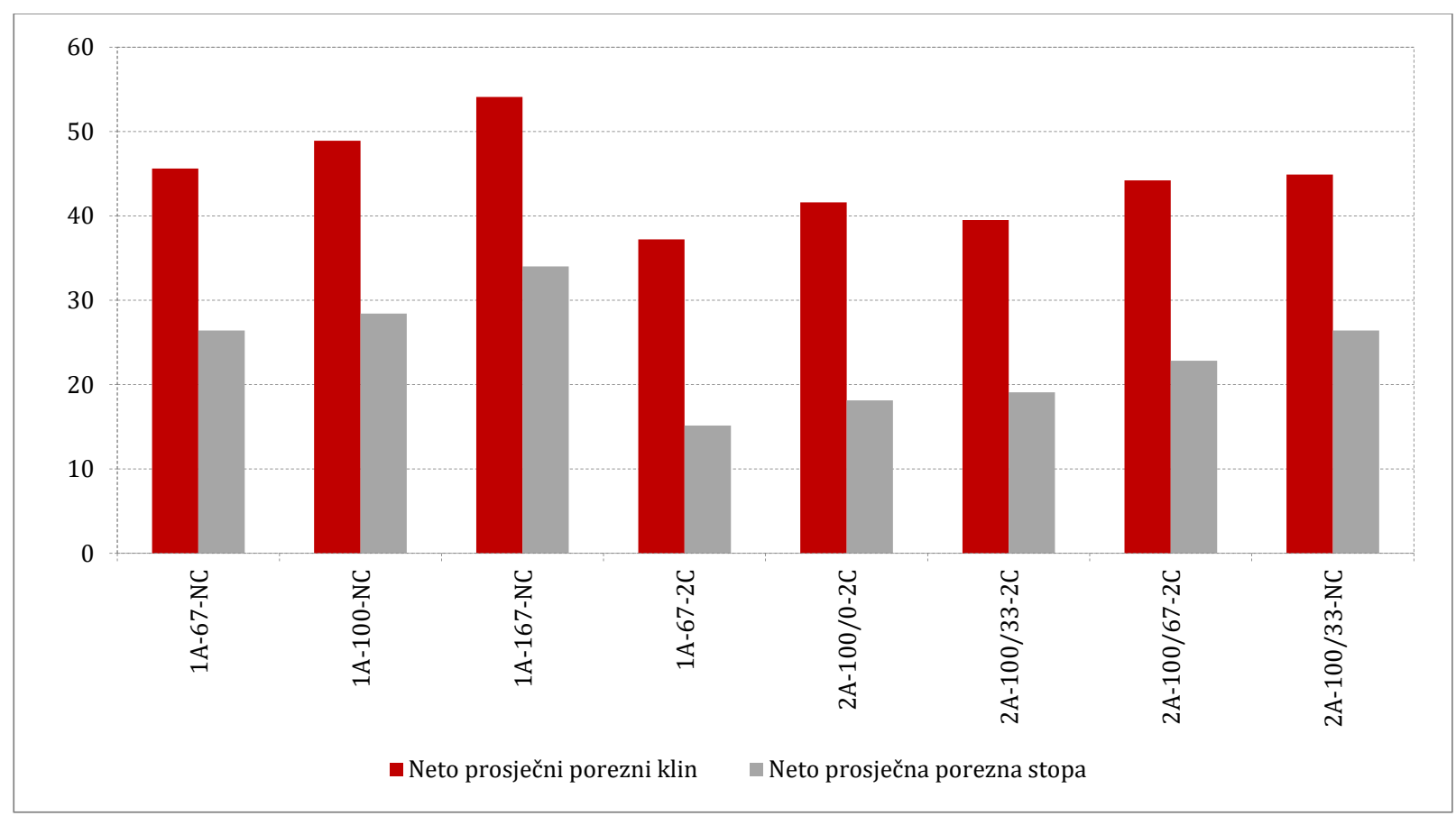

Izvor: autoričini izračuni na temelju OECD-a (2014.). 


\subsection{Portugal}

\subsubsection{OSNOVNI ELEMENTI OPOREZIVANJA DOHOTKA OD RADA U PORTUGALU 2013.}

Prema OECD-u (2014.), posloprimci u Portugalu za doprinose izdvajaju 11\% bruto plaće, dok doprinosi poslodavca iznose $23,75 \%$ bruto plaće. U oba slučaja doprinosi uključuju zdravstveno osiguranje, roditeljski dopust, nezaposlenost i mirovinsko osiguranje.

U Portugalu se porezom na dohodak obuhvaća dohodak cijele obitelji, uključujući i primitke uzdržavane djece. Primjenjuje se metoda zajedničkog oporezivanja uz djelomičnu diobu: zajednički prihod kod parova se dijeli s dva, a zatim se na taj iznos primjenjuju porezne stope kako bi se dobila porezna obveza, koja se onda množi s dva kako bi se dobila zajednička porezna obveza para. Prema Rodrigues et al. (2014.), uzdržavanim djetetom se smatra svako dijete do 18 godina ili do 25 godina ako se školuje i ako su mu mjesečna primanja ispod iznosa minimalne plaće u Portugalu.

Osnovni odbitak jednak je umnošku 72\%*12 (broj mjeseci) i Indeksa socijalnih naknada (uzima se iznos minimalne plaće od 475 eura), a konačan iznos je jednak 4.104 eura. U odbitke pripadaju i doprinosi, ako iznose više od 4.104 eura po poreznom obvezniku. Prema OECD-u (2014.), umanjenje poreza čine: 214 eura za svakog neoženjenog poreznog obveznika ili za svakog supružnika, 333 eura za samohranog roditelja, 214 eura za svako uzdržavano dijete (iznos se udvostručuje ukoliko dijete ima manje od tri godine) i iznos od 261 eura za odrasle članove obitelji (roditelje, bake, djedove), ako im je dohodak manji od minimalnog iznosa za mirovinu. U ostala umanjenja poreza ubrajaju se nenadoknadivi troškove zdravstva koje ne pokriva socijalno osiguranje (olakšica iznosi 10\% ukupnih zdravstvenih troškova s limitom od 838 eura, za svakog uzdržavanog člana iznos limita se povećava za 126 eura), troškovi za obrazovanje (30\% izdataka s limitom od $160 \%$ iznosa minimalne plaće, limit se povećava $30 \%$ za svakog uzdržavanog člana za kojeg se plaćaju troškovi obrazovanja), izdaci za sanatorije i domove za starije i nemoćne osobe (25\% iznosa s limitom od 404 eura), troškovi vezane uz adaptaciju stambenog prostora (15\% iznosa kamata s limitom od 296 eura, a limit se povećava za 50\% ukoliko se porezni obveznik nalazi u prvom poreznom razredu te za $20 \%$ ukoliko se nalazi u drugom poreznom razredu) i troškovi alimentacije (20\% iznosa s mjesečnim limitom od 419 eura).

Ukupna umanjenja poreza vezana za troškove zdravstva, obrazovanje, alimentaciju i stambene troškove nemaju limita, ako je porezna osnovica manja od 7.000 eura; za poreznu osnovicu između 7.000 i 20.000 eura limit iznosi 1.250 eura. Limit se smanjuje s povećanjem osnovice, a za osnovicu iznad 80.000 eura limit iznosi 0, odnosno nema umanjenja poreza.

Ostala umanjenja poreza čine individualna mirovinska štednja u iznosu od 20\% ušteđenog iznosa (za poreznog obveznika do 35 godina limit iznosi 400 eura, između 35 i 50 godina limit je 350 eura, a preko 50 godina limit je 300 eura), zatim $20 \%$ ušteđenog iznosa za individualno socijalno osiguranje s limitom od 350 eura, 25\% iznosa donacija (za škole, knjižnice, muzeje, i slično) s limitom od $15 \%$ porezne osnovice poreznog obveznika i $15 \%$ od iznosa poreza na dodanu vrijednost na određene usluge (restorani, frizeri, automehaničari, i slično) s limitom od 250 eura. Limiti iznose: za poreznu osnovicu do 7.000 eura nema limita; za osnovicu između 7.000 i 20.000 eura limit iznosi 100 eura. Limit se smanjuje s povećanjem osnovice, a za osnovicu iznad 80.000 eura limit iznosi 0 , odnosno nema umanjenja poreza. 
Pri izračunu kojem poreznom razredu porezni obveznik pripada, dohodak se dijeli s dva (tablica 11). Porezna osnovica u Portugalu se izračunava tako da se od iznosa bruto plaće oduzme ukupan iznos standardnih odbitaka i olakšica te doda iznos socijalnih naknada uključenih u poreznu osnovicu (ako postoje). Postoji pet poreznih razreda sa stopama od 14,5\%, 28,5\%, 37\%, 45\% i 48\% koje se primjenjuju ovisno o iznosu porezne osnovice. Prema OECD-u (2014.), u slučaju poreznih obveznika čiji prihod proizlazi prvenstveno iz rada, nakon oporezivanja njihov raspoloživi dohodak ne smije biti manji od 120\% iznosa minimalne plaće (u 2013. je iznosila 8.147 eura).

\section{TABLICA 11.}

Porezne stope i odbitci (Portugal, 2013.)

\begin{tabular}{lcc} 
Porezna osnovica (EUR) & Stopa (\%) & Iznos odbitka (EUR) \\
\hline$<7.000$ & 14,5 & - \\
\hline $7.000-20.000$ & 28,5 & 980 \\
\hline $20.000-40.000$ & 37 & 2.680 \\
\hline $40.000-80.000$ & 45 & 5.880 \\
\hline$>80.000$ & 48 & 8.280 \\
\hline
\end{tabular}

Izvor: OECD (2014.).

Od 2012. postoji i posebni "porez solidarnosti" koji se plaća u iznosu od 2,5\% na poreznu osnovicu između 80.000 i 250.000 eura, odnosno 5\% na poreznu osnovicu iznad 250.000 eura. Naknadno je uveden prirez od 3,5\% za poreznu osnovicu veću od iznosa minimalne plaće (6.790 eura), pri čemu je umanjenje poreza 2,5\% iznosa godišnje minimalne plaće za uzdržavanog člana (170 eura).

Prema OECD-u (2014.), mjesečne naknade za uzdržavanu djecu su podijeljene u 4 razreda ovisno o obiteljskim primanjima, koja se dobiju tako da se ukupna godišnja bruto primanja podijele s brojem uzdržavane djece u obitelji. Ukoliko su primanja po broju djece ispod 2.935 eura, za dijete ispod 12 mjeseci mjesečna naknada iznosi 141 eura, a za dijete starije od godinu dana 35 eura. U obitelji s dvoje djece, svaka sljedeća naknada za dijete između jedne i tri godine iznosi 35 eura, dok ista naknada, ali u obitelji s troje ili više djece iznosi 70 eura. Iznosi se dalje smanjuju s povećanjem razreda. U zadnjem, četvrtom razredu, gdje pripadaju obitelji s primanjima po djeci u iznosu većem od 8.804 eura naknada nema. U slučaju samohranog roditelja navedene naknade se povećavaju za $20 \%$.

\subsubsection{NETO PROSJEČNA POREZNA STOPA I NETO PROSJEČNI POREZNI KLIN U PORTUGALU}

Grafikon 4 prikazuje neto prosječnu poreznu stopu i neto prosječni porezni klin za osam hipotetskih jedinica u Portugalu. Detaljne izračune prikazuju tablice A7 i A8 u dodatku.

Za samce bez djece sustav je progresivan jer neto prosječna porezna stopa i neto prosječni porezni klin rastu s bruto plaćom. Neto prosječni porezni klin kod 1A-167-NC je za 13 postotnih bodova veći nego kod 1A-67-NC. Za parove s dvoje djece sustav je također progresivan. Neto prosječni porezni klin kod 2A-100/0-2C je za 7 postotnih bodova veći nego kod 2A-100/67-2C.

Neto prosječni porezni klin kod jedinice 1A-67-2C niži je 10 postotnih bodova nego za jedinicu 1A67-NC. Porezni klin kod jedinice 2A-100/33-2C niži je 4 postotna boda nego za jedinicu 2A-100/33NC. 


\section{GRAFIKON 4.}

Neto prosječni porezni klin i neto prosječna porezna stopa za hipotetske jedinice (Portugal, 2013.), u \%

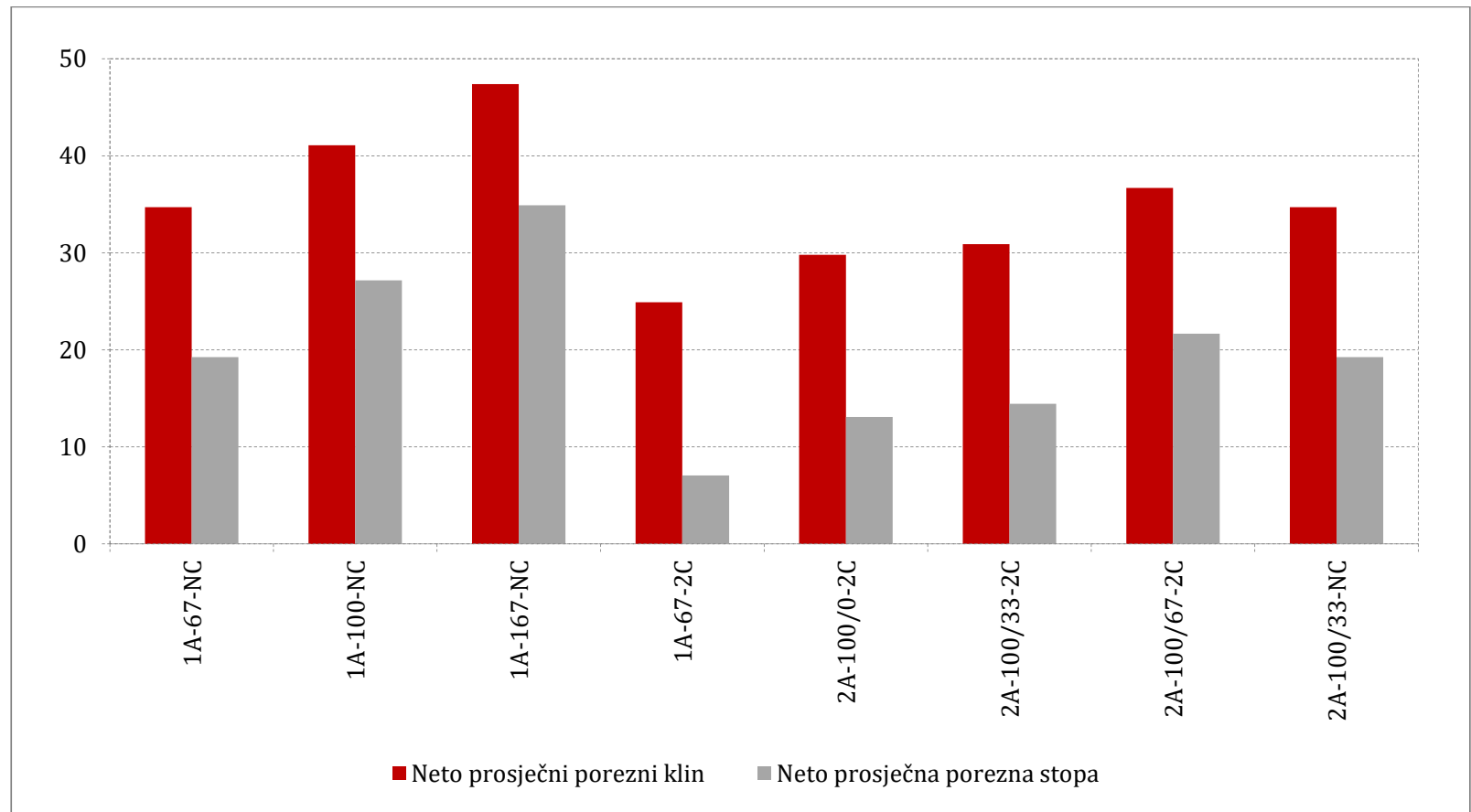

Izvor: autoričini izračuni na temelju OECD-a (2014.).

\subsection{SLOVENIJA}

\subsubsection{OSNOVNI ELEMENTI OPOREZIVANJA DOHOTKA OD RADA U SLOVENIJI 2013.}

U Sloveniji iznos na koji se plaćaju doprinosi posloprimca uključuje bruto plaću, naknade za godišnji odmor i povlastice vezane za rad. Tablica 12 pokazuje koliki postotak doprinosa posloprimca čine doprinosi za mirovinsko osiguranje, za zdravstveno osiguranje, doprinosi za zapošljavanje, te osiguranje za roditeljski dopust. Nabrojane stavke čine ukupno 22,1\% doprinosa posloprimca.

\section{TABLICA 12.}

Stope doprinosa posloprimca (Slovenija, 2013.)

Doprinos Stopa (\%)

Mirovinsko osiguranje 15,5

Zdravstveno osiguranje 6,36

Za zapošljavanje 0,14

Osiguranje za roditeljski dopust 0,1

Ukupno 22,1

Izvor: OECD (2014.).

Na iznos bruto plaće plaćaju se doprinosi poslodavca. Stavke za koje poslodavac izdvaja doprinose su također jednake, a razlika postoji samo u stopama, koje prikazuje tablica 13. Ukupna stopa doprinosa poslodavca iznosi $16,1 \%$. 
TABLICA 13.

Stope doprinosa poslodavca (Slovenija, 2013.)

\begin{tabular}{lc} 
Doprinos & Stopa (\%) \\
\hline Mirovinsko osiguranje & 8,85 \\
\hline Zdravstveno osiguranje & 7,09 \\
\hline Za zapošljavanje & 0,06 \\
\hline Osiguranje za roditeljski dopust & 0,1 \\
\hline Ukupno & 16,1 \\
\hline
\end{tabular}

Izvor: OECD (2014.).

U Sloveniji je porezni obveznik pojedinac. Godišnji osnovni odbitak 2013. iznosio je 3.303 eura. Za osobe s godišnjim dohotkom manjim od 10.866 eura dodatni osnovni odbitak iznosio je 3.217 eura, a između 10.866 i 12.571 eura iznosi 1.116 eura. Prema Kump et al. (2014.), u Sloveniji se uzdržavanim djetetom smatra svako dijete do 18 godina, svako nezaposleno dijete s 18 ili više godina, bez vlastitih prihoda ili s prihodima manjim od olakšice za uzdržavano dijete te ukoliko je još u procesu obrazovanja (redovno školovanje) i pritom ima manje od 26 godina. Tada za prvo dijete osobni odbitak iznosi 2.437, a za drugo 2.649 eura. ${ }^{5}$ Ako je jedan od supružnika nezaposlen, drugi prima osobi odbitak za uzdržavanog člana u iznosu od 2.437 eura. U Sloveniji, kao i u svim zemljama članicama Europske unije, premije za dodatno mirovinsko osiguranje nisu uključene u poreznu osnovicu. U 2013. takvi odbitci imaju godišnji limit od 2.819 eura, odnosno $24 \%$ iznosa doprinosa posloprimca, koji se izdvaja za obavezno mirovinsko osiguranje. Osim toga, postoje izuzeća od oporezivanja za razne naknade vezane uz posao, poput naknada za obrok i prijevoz, troškove poslovnih putovanja, korištenje vlastitih alata i opreme, te bonusi i otpremnine.

Osnovica poreza na dohodak izračunava se tako da se od iznosa bruto plaće oduzme ukupan iznos standardnih odbitaka i olakšica te se dodaje iznos socijalnih naknada uključenih u poreznu osnovicu (ako postoje). Porezne razrede i pripadne stope prikazuje Tablica 14. Postoje četiri porezna razreda sa stopama od $16 \%, 27 \%, 41 \%$ i $50 \%$, koje se primjenjuju ovisno o iznosu porezne osnovice. Regionalni, odnosno lokalni porezi u Sloveniji ne postoje, kao ni porezi na platnu listu (ukinuto 2009.).

TABLICA 14.

Porezni razredi (Slovenija, 2013.)

Porezna osnovica (EUR)

$\begin{array}{ll}<8.021 & 16 \\ 8.021-18.960 & 27 \\ 18.960-70.907 & 41 \\ >70.907 & 50\end{array}$

Izvor: OECD (2014.).

Prema OECD-u (2014.), od 2012. zakonom su propisane naknade za uzdržavanu djecu (do 18 godina), ako je prosječni mjesečni neto dohodak obitelji u prethodnoj kalendarskoj godini niži od prosječne neto plaće. U dohodak ulaze neto plaće te imputirana godišnja korist od nekretnina i pokretnina. Postoji osam razreda ovisno o ukupnom dohotku prema kojima se računa naknada za

5 Za treće dijete olakšica iznosi 4.419, za četvrto 6.188 , za peto 7.957 , te za svako iduće dodatnih 1.769 eura. U slučaju djeteta s posebnim potrebama olakšica iznosi 8.830 eura. 
svako dijete. U prvi razred ulazi obitelj s neto dohotkom manjim od 18\% prosječne neto plaće; u osmi razred ulazi obitelj s neto dohotkom između 82 i 99\% prosječne neto plaće. Godine 2012. došlo je do manjih promjena (naknade za peti i šesti razred su smanjene za 10\%, a za sedmi i osmi razred su ukinute). Svako dijete pripada u jedan od tri razreda (s povećanjem razreda se povećavaju i iznosi naknada), prvo dijete u obitelji pripada u prvi razred, drugo u drugi, a treće i svako sljedeće dijete u treći razred. Ako dijete živi samo s jednim roditeljem, naknada se povećava za $10 \%$, a ako predškolsko dijete ne ide u vrtić, naknada se povećava za $20 \%$.

U Sloveniji postoje i mjesečne naknade za djecu (koja žive s oba roditelja), a država ih isplaćuje od rođenja djeteta pa sve dok dijete ne završi osnovnu školu. Tako je za 2013. maksimalan godišnji iznos, za djecu koja žive s oba roditelja, iznosio 1.372 eura za prvo dijete, 1.509 za drugo, te 1.646 eura za treće i svako sljedeće dijete.

\subsubsection{NETO PROSJEČNA POREZNA STOPA I NETO PROSJEČNI POREZNI KLIN U SLOVENIJI}

Grafikon 5 prikazuje neto prosječnu poreznu stopu i neto prosječni porezni klin za osam hipotetskih jedinica u Sloveniji. Detaljne izračune prikazuju tablice A9 i A10 u dodatku.

Za samce bez djece sustav je progresivan jer neto prosječna porezna stopa i neto prosječni porezni klin rastu s bruto plaćom. Neto prosječni porezni klin kod 1A-167-NC je za 8 postotnih bodova veći nego kod 1A-67-NC. Za parove s dvoje djece sustav je također progresivan. Neto prosječni porezni klin kod 2A-100/0-2C je za 11 postotnih bodova veći nego kod 2A-100/67-2C.

\section{GRAFIKON 5.}

Neto prosječni porezni klin i neto prosječna porezna stopa za hipotetske jedinice (Slovenija, 2013.), u \%

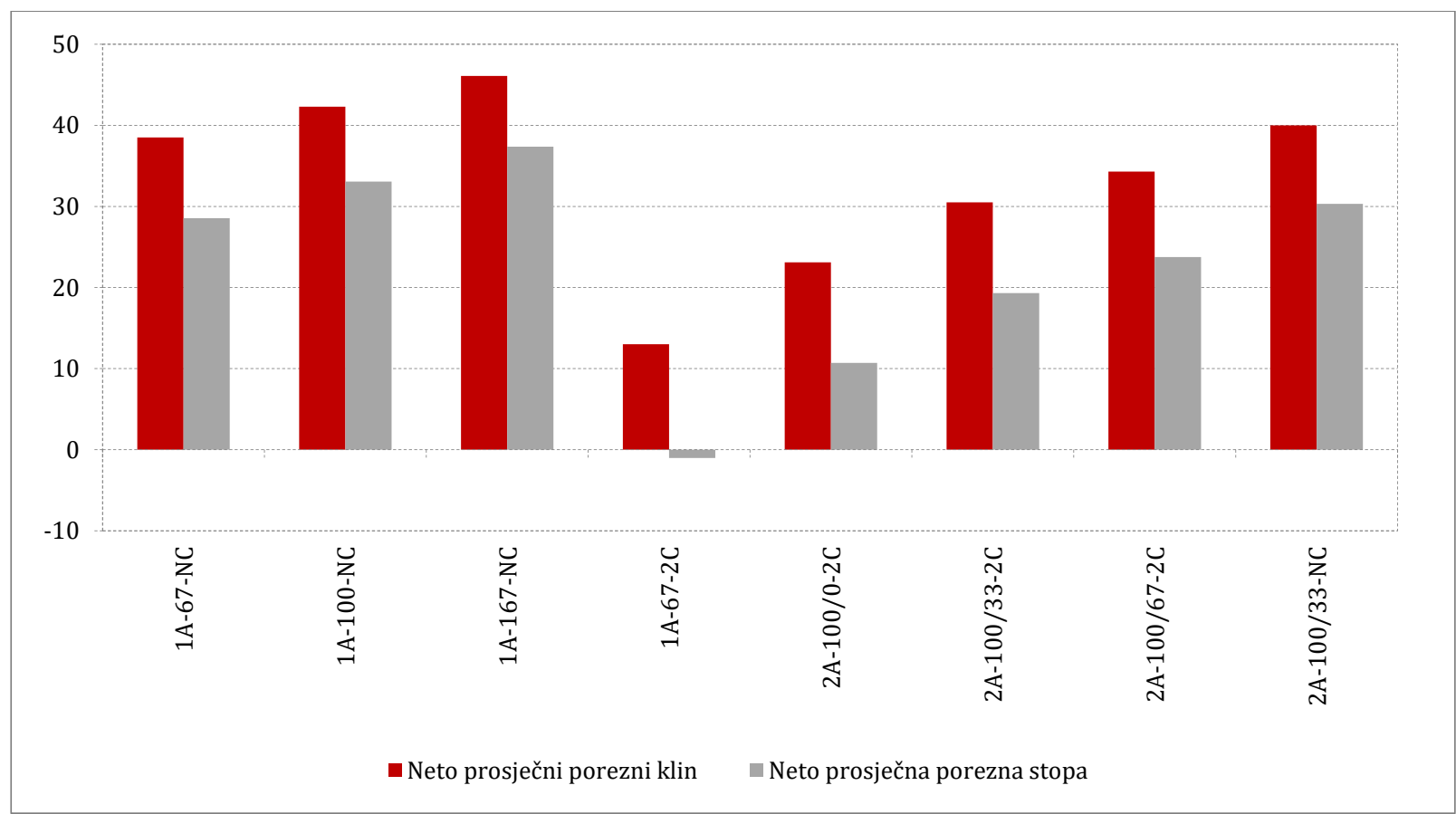

Izvor: autoričini izračuni na temelju OECD-a (2014.).

Neto prosječni porezni klin kod jedinice 1A-67-2C niži je 26 postotnih bodova nego za jedinicu $1 \mathrm{~A}$ 67-NC. Porezni klin kod jedinice 2A-100/33-2C niži je 10 postotnih bodova nego za jedinicu 2A100/33-NC. 


\section{USPOREDBA POREZNOG OPTEREĆENJA RADA U ODABRANIM ZEMLJAMA}

U ovom poglavlju će se usporediti neto prosječni porezni klin svih pet obrađenih zemalja. Od osam hipotetskih jedinica analiziraju se njih četiri, a to su samci bez djece sa $100 \%$ AGW-a (1A-100-NC) i 167\% AGW-a (1A-167-NC), te parovi u kojima jedan supružnik ima 100\%, a drugi 33\% AGW-a, i to bez djece (2A-100/33-NC) i s dvoje djece (2A-100/33-2C). Grafikon 6 prikazuje usporedne rezultate za sve jedinice.

Najniži neto prosječni porezni klin za 1A-100-NC je u Hrvatskoj i iznosi 35,2\%. Na drugom mjestu je Portugal sa 41,1\%, a slijedi Slovenija sa 42,3\%. Na četvrtom mjestu je Češka Republika sa 42,4\%, dok je najviši porezni klin u Francuskoj, gdje iznosi 48,9\%.

Za jedinicu 1A-167-NC poredak je sličan kao u prethodnom slučaju: najniži neto prosječni porezni klin od 39,4\% je u Hrvatskoj, na drugom mjestu je Češka Republika sa 44,9\%, a slijede Slovenija sa 46,1\%, Portugal sa 47,4\% i Francuska s 54,1\%. U odnosu na jedinicu 1A-100-NC, porezni klin kod 1A-167-NC je veći za nekoliko postotnih bodova, što govori o progresivnosti sustava oporezivanja rada. Razlika poreznog klina između 1A-167-NC i 1A-100-NC je najmanja u Češkoj Republici $(2,5$ postotnih bodova), na drugom mjestu je Slovenija (3,8 postotnih bodova), a slijedi Hrvatska (4,2 postotna boda). Na četvrtom mjestu je Francuska (5,2 postotna boda) dok je najveća razlika u Portugalu (6,3 postotnih bodova).

\section{GRAFIKON 6.}

Usporedba neto prosječnog poreznog klina u 2013., za hipotetske jedinice 1A-100-NC, 1A-167-NC, 2A-100/33-NC i $2 A-100 / 33-2 C$, u \%

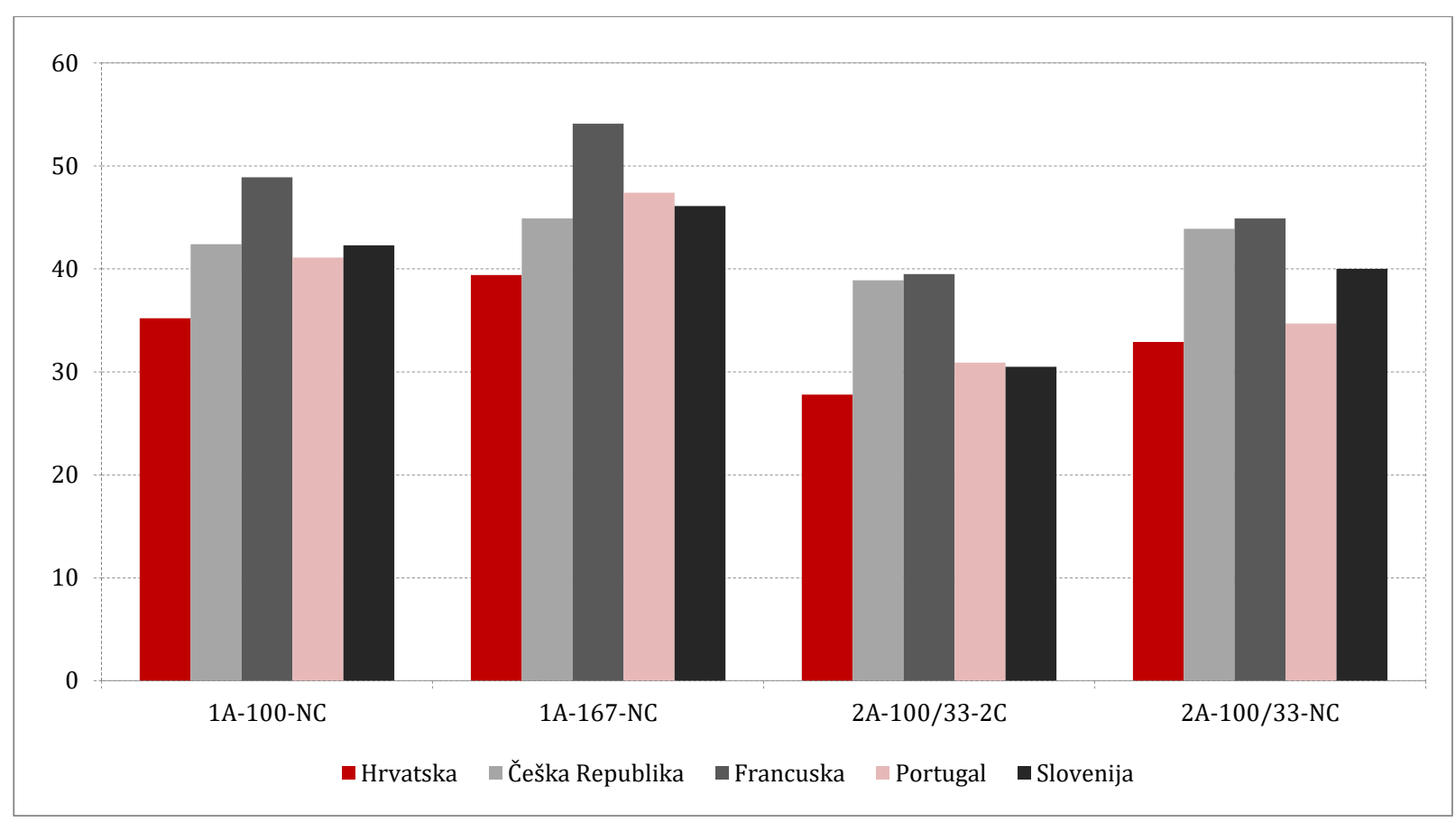

Izvor: autoričini izračuni na temelju OECD-a (2014.).

Kod jedinice 2A-100/33-NC najniži porezni klin je u Hrvatskoj (32,9\%), a slijede Portugal $(34,7 \%)$, Slovenija (40\%), Češka Republika (43,9\%) i Francuska (44,9\%). U slučaju 2A-100/33-2C, najniži porezni klin je u Hrvatskoj (27,8\%), a slijede Slovenija (30,5\%), Portugal (30,9\%), te Češka Republika (38,9\%) i Francuska (39,5\%). 
Kao što je navedeno u analizi po zemljama, parovi i samci s djecom ostvaruju osobne odbitke i umanjenja poreza za djecu u sustavu poreza na dohodak, te dodatno i novčane naknade za djecu. Zbog toga je njihova porezna obveza niža od hipotetskih jedinica koje imaju isti ukupni bruto dohodak, ali nemaju djecu. Na kraju se mogu usporediti razlike u neto prosječnom poreznom klinu 2A-100/33-NC i 2A-100/33-2C. Najviša razlika je u Sloveniji (10 postotnih bodova), a slijede Francuska ( 5 postotnih bodova), Hrvatska ( 5 postotnih bodova) te Češka Republika ( 5 postotnih bodova). Najmanja razlika, od 4 postotna boda, se postiže u Portugalu.

\section{ZAKLJUČAK}

U ovom radu analizirano je porezno opterećenje dohotka od rada u Hrvatskoj, Češkoj Republici, Francuskoj, Portugalu i Sloveniji. Detaljno je prikazan sustav oporezivanja plaća u svim zemljama, kako bi se istakle posebnosti njihovih poreznih sustava, u pogledu poreza na dohodak (osobni odbitci, umanjenja poreza, porezni razredi i stope) te doprinosa za socijalno osiguranje (osnovice i stope). Zatim se za svaku zemlju analiziraju neto prosječna porezna stopa i neto prosječni porezni klin, korištenjem metodologije i podataka iz OECD-ove publikacije Taxing Wages (OECD, 2014.).

Pokazatelji poreznog opterećenja uspoređeni su između zemalja, te unutar svake zemlje, za osam hipotetskih jedinica, koje se razlikuju po broju odraslih članova, razini dohotka, i broju djece. Porezni sustavi u svim odabranim zemljama su progresivni - relativno porezno opterećenje raste s bruto plaćom. Međutim, razlike u poreznom opterećenju između hipotetskih jedinica s većim i manjim bruto dohotkom nisu jednake u svim zemljama.

Također se moglo uočiti da zemlje, koristeći odbitke i umanjenja poreza te novčane naknade za obitelj, na različite načine i u različitom intenzitetu smanjuju porezno opterećenje za jedinice $s$ 18 djecom u odnosu na jedinice bez djece.

Što se visine neto prosječnog poreznog klina tiče, on se pokazao najvišim u Francuskoj, a najniži je u Hrvatskoj, i to za sve promatrane hipotetske jedinice.

Analiza je ukazala na mogućnosti "uvoza" nekih elemenata sustava poreznih olakšica i naknada za obitelj u hrvatski sustav. Primjerice, Urban (2014.) pokazuje da obitelji s prosječnim dohotkom ne ostvaruju doplatak za djecu, a također ne ostvaruju uštedu od odbitka za djecu u obliku niže plaćenog poreza na dohodak. Taj problem mogao bi se riješiti, primjerice, uvođenjem instrumenta umanjenja poreza kakav postoji u Češkoj Republici, pri čemu konačni iznos poreza može biti negativan ako je iznos umanjenja poreza viši od početne porezne obveze (tzv. refundable tax credit). 


\section{REFERENCE}

1. Avram, S., i Bouvard, L., 2014. EUROMOD Country Report: France 2009-2013. [online] Dostupno na: <https://www.iser.essex.ac.uk/files/euromod/country-reports/Year5/CR_FR_Y5_withAnnex_final_12032014.pdf >.

2. Blažić, H., i Trošelj, I., 2012. Međunarodna usporedba poreznog opterećenja radne snage: utjecaj nove metodologije na položaj Hrvatske. U: L. Božina, M. Gonan-Božac i D. Učkar, ur. Financije i menadžment u globalnoj ekonomiji. Pula: Sveučilište Jurja Dobrile u Puli, Odjel za ekonomiju i turizam, str. 185-204.

3. DZS, 2015. Statistički ljetopis Republike Hrvatske 2015. [online] Dostupno na: <http://www.dzs.hr/Hrv_Eng/ljetopis/2014/sljh2014.pdf>.

4. DZS, 2016. Statistika u nizu: Zaposlenost i plaće. [online] Dostupno na: <http://www.dzs.hr/Hrv_Eng/Pokazatelji/MSI ZAPOSLENOST I PLACE.xlsx>.

5. HNB, 2016. CNB midpoint exchange rate. [online] Dostupno na:<http://www.hnb.hr/en/statistics/statistical-data/central-bank-cnb/cnb-midpointexchange-rate>.

6. Kalíšková, K., Münich, D. i Pavel, J., 2014. EUROMOD Country Report: Czech Republic 2009-2013. [online] Dostupno na: <https://www.iser.essex.ac.uk/files/euromod/country-reports/Year5/CR_CZ_2009-2013_final_12032014.pdf>.

7. Kump, N., Čok, M. i Majcen, B., 2014. EUROMOD Country Report: Slovenia 2009-2013. [online] Dostupno na: <https://www.iser.essex.ac.uk/files/euromod/country-reports/Year5/CR_SI_2009-2013_final_12032014.pdf>.

8. OECD, 2014. Taxing Wages 2014. Paris: OECD.

9. OECD, 2015. Non-tax compulsory payments as an additional burden on labour income. [online] Dostupno na: <http://www.oecd.org/tax/tax-policy/Non-tax-compuslory-payments2014.pdf>.

10. Rodrigues, C.F., Junqueira, V. i Figueiras, R., 2014. EUROMOD Country Report: Portugal 20092013. [online] Dostupno na: <https://www.iser.essex.ac.uk/files/euromod/country-reports/Year5/CR_PT_Y5_Jan2014_final_12032014.pdf>.

11. Urban, I., 2014. Potpore za kućanstva s djecom. Newsletter, Zagreb: Institut za javne financije.

12. Urban, I., 2016. Tax wedge on labour income in Croatia and the European Union. Financial Theory and Practice, 40(2), str. 157-168. doi: 10.3326/fintp.40.2.1

13. Uredba o visini minimalne plaće za 2013., NN 51/13. [online] Dostupno na: <http://narodnenovine.nn.hr/clanci/sluzbeni/2013_04_51_1016.html>.

14. Zakon o doplatku za djecu, NN 94/01., 138/06., 107/07., 37/08., 61/11., 112/12., 82/15. [online] Dostupno na: <http://www.zakon.hr/z/475/zakon-o-doplatku-za-djecu>.

15. Zakon o doprinosima, NN 84/08., 152/08., 94/09., 18/11., 22/12., 144/12., 148/13., 41/14. [online] Dostupno na: <http://www.zakon.hr/z/365/Zakon-o-Contributionima>.

16. Zakon o porezu na dohodak, NN 177/04., 73/08., 80/10., 114/11., 22/12., 144/12., 43/13., 120/13., 125/13., 148/13., 83/14., 143/14. [online] Dostupno na: <http://www.zakon.hr/z/85-/Zakon-o-porezu-na-dohodak>. 


\section{DODATAK \\ TABLICE OPOREZIVANJA DOHOTKA HIPOTETSKIH JEDINICA U SVIM ODABRANIM ZEMLJAMA}

\section{TABLICA A1.}

Oporezivanje dohotka hipotetskih jedinica: samaca (Hrvatska, 2013.)

\begin{tabular}{|c|c|c|c|c|}
\hline & 1A-67-NC & 1A-100-NC & 1A-167-NC & 1A-67-2C \\
\hline 1. Bruto plaća (EUR) & 8.202 & 12.303 & 20.506 & 8.202 \\
\hline 2. Doprinosi poslodavca & 1.247 & 1.870 & 3.117 & 1.247 \\
\hline 3. Porez na platnu listu & 0 & 0 & 0 & 0 \\
\hline 4. Doprinosi posloprimca & 1.640 & 2.461 & 4.101 & 1.640 \\
\hline 4.1. Za prvi stup mirovinskog osiguranja & 1.230 & 1.845 & 3.076 & 1.230 \\
\hline 4.2. Za drugi stup mirovinskog osiguranja & 410 & 615 & 1.025 & 410 \\
\hline \multicolumn{5}{|l|}{ 5. Porezi na dohodak posloprimca } \\
\hline \multicolumn{5}{|l|}{ 5.1. Standardni odbitci i olakšice } \\
\hline 5.1.1. Osnovni & 3.486 & 3.486 & 3.486 & 3.486 \\
\hline 5.1.2. Za oženjene ili glavu obitelji & 0 & 0 & 0 & 0 \\
\hline 5.1.3. Za djecu & 0 & 0 & 0 & 4.183 \\
\hline 5.1.4. Odbitak za doprinose & 0 & 0 & 0 & 0 \\
\hline 5.1.5. Troškovi vezani za rad & 0 & 0 & 0 & 0 \\
\hline 5.1.6. Ukupno & 3.486 & 3.486 & 3.486 & 7.669 \\
\hline 5.2. Novčane naknade uključene u poreznu osnovicu & 0 & 0 & 0 & 0 \\
\hline 5.3. Porezna osnovica & 3.076 & 6.357 & 12.919 & 0 \\
\hline 5.4. Porez na dohodak prije umanjenja poreza & 369 & 1.136 & 2.777 & 0 \\
\hline 5.5. Umanjenje poreza & 0 & 0 & 0 & 0 \\
\hline 5.6. Porez na dohodak nakon umanjenja poreza & 369 & 1.136 & 2.777 & 0 \\
\hline 5.7. Prirez porezu na dohodak & 44 & 136 & 333 & 0 \\
\hline 5.8. Neto ukupni iznos poreza na dohodak & 413 & 1.272 & 3.110 & 0 \\
\hline 6. Ukupni porezi i doprinosi posloprimca & 2.053 & 3.733 & 7.211 & 1.640 \\
\hline 6.1. Porezna davanja & 1.643 & 3.117 & 6.186 & 1.230 \\
\hline 6.2. Neporezna davanja & 410 & 615 & 1.025 & 410 \\
\hline
\end{tabular}

7. Novčane naknade za obitelj

\begin{tabular}{lrrrr}
\hline 7.1. Za člana obitelji & 0 & 0 & 0 & 0 \\
\hline 7.2. Za djecu & 0 & 0 & 0 & 727 \\
\hline 7.3. Ukupno & 0 & 0 & 0 & 727 \\
\hline 8. Neto dohodak & 6.149 & 8.570 & 13.295 & 6.562 \\
\hline 9. Neto prosječna porezna stopa (u \%) & 20,0 & 25,3 & 30,2 & 6,1 \\
\hline 10. Neto prosječni porezni klin (u \%) & 30,6 & 35,2 & 39,4 & 18,5 \\
\hline
\end{tabular}

Napomena: doprinosi posloprimca za drugi stup mirovinskog osiguranja ne ulaze u porezna davanja prema Taxing Wages metodologiji (OECD, 2014.). Stoga je stavka 6. podijeljena na porezna i neporezna davanja, pri čemu samo porezna davanja ulaze u izračun pokazatelja poreznog opterećenja.

Izvor: autoričini izračuni. 
TABLICA A2.

Oporezivanje dohotka hipotetskih jedinica: parova (Hrvatska, 2013.)

$2 A-100 / 0-2 C \quad 2 A-100 / 33-2 C \quad 2 A-100 / 67-2 C \quad 2 A-100 / 33-N C$

\begin{tabular}{|c|c|c|c|c|}
\hline 1. Bruto plaća (EUR) & 12.303 & 16.405 & 20.506 & 16.405 \\
\hline 2. Doprinosi poslodavca & 1.870 & 2.493 & 3.117 & 2.493 \\
\hline 3. Porez na platnu listu & 0 & 0 & 0 & 0 \\
\hline 4. Doprinosi posloprimca & 2.461 & 3.281 & 4.101 & 3.281 \\
\hline 4.1. Za prvi stup mirovinskog osiguranja & 1.845 & 2.461 & 3.076 & 2.461 \\
\hline $\begin{array}{l}\text { 4.2. Za drugi stup mirovinskog } \\
\text { osiguranja }\end{array}$ & 615 & 820 & 1.025 & 820 \\
\hline \multicolumn{5}{|l|}{ 5. Porezi na dohodak posloprimca } \\
\hline \multicolumn{5}{|l|}{ 5.1. Standardni odbitci i olakšice } \\
\hline 5.1.1. Osnovni & 3.486 & 6.972 & 6.972 & 6.972 \\
\hline 5.1.2. Za uzdržavanog člana & 1.743 & 0 & 0 & 0 \\
\hline 5.1.3. Za djecu & 4.183 & 4.183 & 4.183 & 0 \\
\hline 5.1.4. Odbitak za doprinose & 0 & 0 & 0 & 0 \\
\hline 5.1.5. Troškovi vezani za rad & 0 & 0 & 0 & 0 \\
\hline 5.1.6. Ukupno & 9.412 & 11.155 & 11.155 & 6.972 \\
\hline $\begin{array}{l}\text { 5.2. Novčane naknade uključene u } \\
\text { poreznu osnovicu }\end{array}$ & 0 & 0 & 0 & 0 \\
\hline 5.3. Porezna osnovica & 431 & 2.174 & 5.250 & 6.357 \\
\hline $\begin{array}{l}\text { 5.4. Porez na dohodak prije umanjenja } \\
\text { poreza }\end{array}$ & 52 & 261 & 630 & 1.136 \\
\hline 5.5. Umanjenje poreza & 0 & 0 & 0 & 0 \\
\hline $\begin{array}{l}\text { 5.6. Porez na dohodak nakon umanjenja } \\
\text { poreza }\end{array}$ & 52 & 261 & 630 & 1.136 \\
\hline 5.7. Prirez porezu na dohodak & 6 & 31 & 76 & 136 \\
\hline $\begin{array}{l}\text { 5.8. Konačni iznos poreza na dohodak } \\
\text { posloprimca }\end{array}$ & 58 & 292 & 706 & 1.272 \\
\hline 6. Ukupni porezi i doprinosi posloprimca & 2.519 & 3.573 & 4.807 & 4.553 \\
\hline 6.1. Porezna davanja & 1.903 & 2.753 & 3.782 & 3.733 \\
\hline 6.2. Neporezna davanja & 615 & 820 & 1.025 & 820 \\
\hline
\end{tabular}

7. Novčane naknade za obitelj

\begin{tabular}{lrrrr}
\hline 7.1. Za člana obitelji & 0 & 0 & 0 & 0 \\
\hline 7.2. Za djecu & 632 & 0 & 0 & 0 \\
\hline 7.3. Ukupno & 632 & 0 & 0 & 0 \\
\hline 8. Neto dohodak & 9.785 & 12.831 & 15.699 & 11.851 \\
\hline 9. Neto prosječna porezna stopa (u \%) & 10,3 & 16,8 & 18,4 & 22,8 \\
\hline 10. Neto prosječni porezni klin (u \%) & 22,2 & 27,8 & 29,2 & 32,9 \\
\hline
\end{tabular}

Napomena: vidjeti napomenu za tablicu A1.

Izvor: autoričini izračuni. 
TABLICA A3.

Oporezivanje dohotka hipotetskih jedinica: samaca (Češka Republika, 2013.)

\begin{tabular}{|c|c|c|c|c|}
\hline & 1A-67-NC & 1A-100-NC & 1A-167-NC & 1A-67-2C \\
\hline 1. Bruto plaća (EUR) & 7.637 & 11.455 & 19.091 & 7.637 \\
\hline 2. Doprinosi poslodavca & 2.596 & 3.895 & 6.491 & 2.596 \\
\hline 3. Porez na platnu listu & 0 & 0 & 0 & 0 \\
\hline 4. Doprinosi posloprimca & 840 & 1.260 & 2.100 & 840 \\
\hline \multicolumn{5}{|l|}{ 5. Porezi na dohodak posloprimca } \\
\hline \multicolumn{5}{|l|}{ 5.1. Standardni odbitci i olakšice } \\
\hline 5.1.1. Osnovni & 0 & 0 & 0 & 0 \\
\hline 5.1.2. Za oženjene ili glavu obitelji & 0 & 0 & 0 & 0 \\
\hline 5.1.3. Za djecu & 0 & 0 & 0 & 0 \\
\hline 5.1.4. Odbitak za doprinose & 0 & 0 & 0 & 0 \\
\hline 5.1.5. Troškovi vezani za rad & 0 & 0 & 0 & 0 \\
\hline 5.1.6. Ukupno & 0 & 0 & 0 & 0 \\
\hline 5.2. Novčane naknade uključene u poreznu osnovicu & 0 & 0 & 0 & 0 \\
\hline 5.3. Porezna osnovica & 10.233 & 15.350 & 25.582 & 10.233 \\
\hline 5.4. Porez na dohodak prije umanjenja poreza & 1.535 & 2.302 & 3.837 & 1.535 \\
\hline 5.5. Umanjenje poreza & 952 & 952 & 952 & 1.980 \\
\hline 5.6. Porez na dohodak nakon umanjenja poreza & 583 & 1.350 & 2.885 & -445 \\
\hline 5.7. Prirez porezu na dohodak & 0 & 0 & 0 & 0 \\
\hline 5.8. Neto ukupni iznos poreza na dohodak & 583 & 1.350 & 2.885 & -445 \\
\hline 6. Ukupni porezi i doprinosi posloprimca & 1.423 & 2.610 & 4.985 & 395 \\
\hline \multicolumn{5}{|l|}{ 7. Novčane naknade za obitelj } \\
\hline 7.1. Za člana obitelji & 0 & 0 & 0 & 0 \\
\hline 7.2. Za djecu & 0 & 0 & 0 & 1.524 \\
\hline 7.3. Ukupno & 0 & 0 & 0 & 1.524 \\
\hline 8. Neto dohodak & 6.214 & 8.845 & 14.106 & 8.766 \\
\hline 9. Neto prosječna porezna stopa (u \%) & 7,6 & 11,8 & 15,1 & $-5,8$ \\
\hline 10. Neto prosječni porezni klin (u \%) & 39,3 & 42,4 & 44,9 & 14,3 \\
\hline
\end{tabular}

Izvor: autoričini izračuni na temelju OECD -a (2014.). 
TABLICA A4.

Oporezivanje dohotka hipotetskih jedinica: parova (Češka Republika, 2013.)

$2 A-100 / 0-2 C \quad 2 A-100 / 33-2 C \quad 2 A-100 / 67-2 C \quad 2 A-100 / 33-N C$

\begin{tabular}{lrrrr}
\hline 1. Bruto plaća (EUR) & 11.455 & 15.273 & 19.091 & 15.273 \\
\hline 2. Doprinosi poslodavca & 3.895 & 5.193 & 6.491 & 5.193 \\
\hline 3. Porez na platnu listu & 0 & 0 & 0 & 0 \\
\hline 4. Doprinosi posloprimca & 1.260 & 1.680 & 2.100 & 1.680 \\
\hline 5. Porezi na dohodak posloprimca & & & & \\
\hline
\end{tabular}

5.1. Standardni odbitci i olakšice

\begin{tabular}{|c|c|c|c|c|}
\hline 5.1.1. Osnovni & 0 & 0 & 0 & 0 \\
\hline 5.1.2. Za oženjene ili glavu obitelji & 0 & 0 & 0 & 0 \\
\hline 5.1.3. Za djecu & 0 & 0 & 0 & 0 \\
\hline 5.1.4. Odbitak za doprinose & 0 & 0 & 0 & 0 \\
\hline 5.1.5. Troškovi vezani za rad & 0 & 0 & 0 & 0 \\
\hline 5.1.6. Ukupno & 0 & 0 & 0 & 0 \\
\hline $\begin{array}{l}\text { 5.2. Novčane naknade uključene u } \\
\text { poreznu osnovicu }\end{array}$ & 0 & 0 & 0 & 0 \\
\hline 5.3. Porezna osnovica & 15.349 & 20.466 & 25.582 & 20.466 \\
\hline $\begin{array}{l}\text { 5.4. Porez na dohodak prije umanjenja } \\
\text { poreza }\end{array}$ & 2.302 & 3.070 & 3.837 & 3.070 \\
\hline 5.5. Umanjenje poreza & 2.933 & 1.980 & 1.980 & 952 \\
\hline $\begin{array}{l}\text { 5.6. Porez na dohodak nakon umanjenja } \\
\text { poreza }\end{array}$ & -630 & 1.090 & 1.857 & 2.118 \\
\hline 5.7. Prirez porezu na dohodak & 0 & 0 & 0 & 0 \\
\hline $\begin{array}{l}\text { 5.8. Neto ukupni iznos poreza na } \\
\text { dohodak }\end{array}$ & -630 & 1.090 & 1.857 & 2.118 \\
\hline 6. Ukupni porezi i doprinosi posloprimca & 630 & 2.770 & 3.957 & 3.798 \\
\hline \multicolumn{5}{|l|}{ 7. Novčane naknade za obitelj } \\
\hline 7.1. Za člana obitelji & 0 & 0 & 0 & 0 \\
\hline 7.2. Za djecu & 1.378 & 1.118 & 818 & 0 \\
\hline 7.3. Ukupno & 1.378 & 1.118 & 818 & 0 \\
\hline 8. Neto dohodak & 12.203 & 13.621 & 15.952 & 11.475 \\
\hline 9. Neto prosječna porezna stopa (u \%) & $-5,5$ & 7,1 & 9,7 & 13,9 \\
\hline 10. Neto prosječni porezni klin (u \%) & 29,5 & 38,9 & 40,8 & 43,9 \\
\hline
\end{tabular}

Izvor: autoričini izračuni na temelju OECD-a (2014.). 
TABLICA A5.

Oporezivanje dohotka hipotetskih jedinica: samaca (Francuska, 2013.)

\begin{tabular}{|c|c|c|c|c|}
\hline & 1A-67-NC & 1A-100-NC & 1A-167-NC & $1 A-67-2 C$ \\
\hline 1. Bruto plaća (EUR) & 24.653 & 36.980 & 61.633 & 24.653 \\
\hline 2. Doprinosi poslodavca & 8.685 & 14.851 & 27.020 & 8.685 \\
\hline 3. Porez na platnu listu & 0 & 0 & 0 & 0 \\
\hline 4. Doprinosi posloprimca & 3.402 & 5.103 & 8.099 & 3.402 \\
\hline \multicolumn{5}{|l|}{ 5. Porezi na dohodak posloprimca } \\
\hline \multicolumn{5}{|l|}{ 5.1. Standardni odbitci i olakšice } \\
\hline 5.1.1. Osnovni & 0 & 0 & 0 & 0 \\
\hline 5.1.2. Za oženjene ili glavu obitelji & 0 & 0 & 0 & 0 \\
\hline 5.1.3. Za djecu & 0 & 0 & 0 & 0 \\
\hline 5.1.4. Odbitak za doprinose & 4.637 & 6.956 & 11.188 & 4.637 \\
\hline 5.1.5. Troškovi vezani za rad & 2.002 & 3.002 & 5.045 & 2.002 \\
\hline 5.1.6. Ukupno & 6.639 & 9.959 & 16.232 & 6.639 \\
\hline 5.2. Novčane naknade uključene u poreznu osnovicu & 0 & 0 & 0 & 0 \\
\hline 5.3. Porezna osnovica & 18.014 & 27.021 & 45.401 & 18.014 \\
\hline 5.4. Porez na dohodak prije umanjenja poreza & 3.110 & 5.402 & 12.854 & 1.938 \\
\hline 5.5. Umanjenje poreza & 0 & 0 & 0 & 72 \\
\hline 5.6. Porez na dohodak nakon umanjenja poreza & 3.110 & 5.402 & 12.854 & 1.866 \\
\hline 5.7. Prirez porezu na dohodak & 0 & 0 & 0 & 0 \\
\hline 5.8. Neto ukupni iznos poreza na dohodak & 3.110 & 5.402 & 12.854 & 1.866 \\
\hline 6. Ukupni porezi i doprinosi posloprimca & 6.512 & 10.506 & 20.953 & 5.268 \\
\hline \multicolumn{5}{|l|}{ 7. Novčane naknade za obitelj } \\
\hline 7.1. Za člana obitelji & 0 & 0 & 0 & 0 \\
\hline 7.2. Za djecu & 0 & 0 & 0 & 1.538 \\
\hline 7.3. Ukupno & 0 & 0 & 0 & 1.538 \\
\hline 8. Neto dohodak & 18.141 & 26.475 & 40.680 & 20.924 \\
\hline 9. Neto prosječna porezna stopa (u \%) & 12,6 & 14,6 & 20,9 & 7,6 \\
\hline 10. Neto prosječni porezni klin (u \%) & 45,6 & 48,9 & 54,1 & 37,2 \\
\hline
\end{tabular}

Izvor: autoričini izračuni na temelju OECD-a (2014.). 
TABLICA A6.

Oporezivanje dohotka hipotetskih jedinica: parova (Francuska, 2013.)

2A-100/0-2C 2A-100/33-2C 2A-100/67-2C 2A-100/33-NC

\begin{tabular}{lrrrr}
\hline 1. Bruto plaća (EUR) & 36.980 & 49.307 & 61.633 & 49.307 \\
\hline 2. Doprinosi poslodavca & 14.851 & 16.597 & 23.536 & 16.597 \\
\hline 3. Porez na platnu listu & 0 & 0 & 0 & 0 \\
\hline 4. Doprinosi posloprimca & 5.103 & 6.804 & 8.505 & 6.804 \\
\hline 5. Porezi na dohodak posloprimca & & & &
\end{tabular}

5.1. Standardni odbitci i olakšice

\begin{tabular}{|c|c|c|c|c|}
\hline 5.1.1. Osnovni & 0 & 0 & 0 & 0 \\
\hline 5.1.2. Za oženjene ili glavu obitelji & 0 & 0 & 0 & 0 \\
\hline 5.1.3. Za djecu & 0 & 0 & 0 & 0 \\
\hline 5.1.4. Odbitak za doprinose & 6.956 & 9.275 & 11.594 & 9.275 \\
\hline 5.1.5. Troškovi vezani za rad & 3.002 & 4.003 & 5.004 & 4.003 \\
\hline 5.1.6. Ukupno & 9.959 & 13.278 & 16.598 & 13.278 \\
\hline $\begin{array}{l}\text { 5.2. Novčane naknade uključene u } \\
\text { poreznu osnovicu }\end{array}$ & 0 & 0 & 0 & 0 \\
\hline 5.3. Porezna osnovica & 27.021 & 36.029 & 45.036 & 36.029 \\
\hline $\begin{array}{l}\text { 5.4. Porez na dohodak prije umanjenja } \\
\text { poreza }\end{array}$ & 3.140 & 4.859 & 7.100 & 6.220 \\
\hline 5.5. Umanjenje poreza & 0 & 722 & 0 & 0 \\
\hline $\begin{array}{l}\text { 5.6. Porez na dohodak nakon umanjenja } \\
\text { poreza }\end{array}$ & 3.140 & 4.137 & 7.100 & 6.220 \\
\hline 5.7. Prirez porezu na dohodak & 0 & 0 & 0 & 0 \\
\hline $\begin{array}{l}\text { 5.8. Neto ukupni iznos poreza na } \\
\text { dohodak }\end{array}$ & 3.140 & 4.137 & 7.100 & 6.220 \\
\hline 6. Ukupni porezi i doprinosi posloprimca & 8.243 & 10.942 & 15.605 & 13.024 \\
\hline \multicolumn{5}{|l|}{ 7. Novčane naknade za obitelj } \\
\hline 7.1. Za člana obitelji & 0 & 0 & 0 & 0 \\
\hline 7.2. Za djecu & 1.538 & 1.538 & 1.538 & 0 \\
\hline 7.3. Ukupno & 1.538 & 1.538 & 1.538 & 0 \\
\hline 8. Neto dohodak & 30.275 & 39.903 & 47.566 & 36.283 \\
\hline 9. Neto prosječna porezna stopa (u \%) & 8,5 & 8,4 & 11,5 & 12,6 \\
\hline 10. Neto prosječni porezni klin (u \%) & 41,6 & 39,5 & 44,2 & 44,9 \\
\hline
\end{tabular}

Izvor: autoričini izračuni na temelju OECD-a (2014.). 
TABLICA A7.

Oporezivanje dohotka hipotetskih jedinica: samaca (Portugal, 2013.)

\begin{tabular}{|c|c|c|c|c|}
\hline & 1A-67-NC & 1A-100-NC & 1A-167-NC & 1A-67-2C \\
\hline 1. Bruto plaća (EUR) & 11.557 & 17.335 & 28.892 & 11.557 \\
\hline 2. Doprinosi poslodavca & 2.745 & 4.117 & 6.862 & 2.745 \\
\hline 3. Porez na platnu listu & 0 & 0 & 0 & 0 \\
\hline 4. Doprinosi posloprimca & 1.271 & 1.907 & 3.178 & 1.271 \\
\hline \multicolumn{5}{|l|}{ 5. Porezi na dohodak posloprimca } \\
\hline \multicolumn{5}{|l|}{ 5.1. Standardni odbitci i olakšice } \\
\hline 5.1.1. Osnovni & 4.104 & 4.104 & 4.104 & 4.104 \\
\hline 5.1.2. Za oženjene ili glavu obitelji & 0 & 0 & 0 & 0 \\
\hline 5.1.3. Za djecu & 0 & 0 & 0 & 0 \\
\hline 5.1.4. Odbitak za doprinose & 0 & 0 & 0 & 0 \\
\hline 5.1.5. Troškovi vezani za rad & 0 & 0 & 0 & 0 \\
\hline 5.1.6. Ukupno & 4.104 & 4.104 & 4.104 & 4.104 \\
\hline 5.2. Novčane naknade uključene u poreznu osnovicu & 0 & 0 & 0 & 0 \\
\hline 5.3. Porezna osnovica & 7.453 & 13.231 & 24.788 & 7.453 \\
\hline 5.4. Porez na dohodak prije umanjenja poreza & 1.144 & 2.791 & 6.492 & 1.144 \\
\hline 5.5. Umanjenje poreza & 214 & 214 & 214 & 760 \\
\hline 5.6. Porez na dohodak nakon umanjenja poreza & 954 & 2.803 & 6.908 & 384 \\
\hline 5.7. Prirez porezu na dohodak & 0 & 0 & 0 & 0 \\
\hline 5.8. Neto ukupni iznos poreza na dohodak & 954 & 2.803 & 6.908 & 384 \\
\hline 6. Ukupni porezi i doprinosi posloprimca & 2.225 & 4.710 & 10.086 & 1.655 \\
\hline \multicolumn{5}{|l|}{ 7. Novčane naknade za obitelj } \\
\hline 7.1. Za člana obitelji & 0 & 0 & 0 & 0 \\
\hline 7.2. Za djecu & 0 & 0 & 0 & 841 \\
\hline 7.3. Ukupno & 0 & 0 & 0 & 841 \\
\hline 8. Neto dohodak & 9.332 & 12.626 & 18.806 & 10.742 \\
\hline 9. Neto prosječna porezna stopa (u \%) & 8,3 & 16,2 & 23,9 & 3,3 \\
\hline 10. Neto prosječni porezni klin (u \%) & 34,7 & 41,1 & 47,4 & 24,9 \\
\hline
\end{tabular}

Izvor: autoričini izračuni na temelju OECD-a (2014.). 
TABLICA A8.

Oporezivanje dohotka hipotetskih jedinica: parova (Portugal, 2013.)

2A-100/0-2C 2A-100/33-2C 2A-100/67-2C 2A-100/33-NC

\begin{tabular}{|c|c|c|c|c|}
\hline 1. Bruto plaća (EUR) & 17.335 & 23.114 & 28.892 & 23.114 \\
\hline 2. Doprinosi poslodavca & 4.117 & 5.490 & 6.862 & 5.490 \\
\hline 3. Porez na platnu listu & 0 & 0 & 0 & 0 \\
\hline 4. Doprinosi posloprimca & 1.907 & 2.543 & 3.178 & 2.543 \\
\hline \multicolumn{5}{|l|}{ 5. Porezi na dohodak posloprimca } \\
\hline \multicolumn{5}{|l|}{ 5.1. Standardni odbitci i olakšice } \\
\hline 5.1.1. Osnovni & 4.104 & 8.208 & 8.208 & 8.208 \\
\hline 5.1.2. Za uzdržavanog člana & 0 & 0 & 0 & 0 \\
\hline 5.1.3. Za djecu & 0 & 0 & 0 & 0 \\
\hline 5.1.4. Odbitak za doprinose & 0 & 0 & 0 & 0 \\
\hline 5.1.5. Troškovi vezani za rad & 0 & 0 & 0 & 0 \\
\hline 5.1.6. Ukupno & 4.104 & 8.208 & 8.208 & 8.208 \\
\hline $\begin{array}{l}\text { 5.2. Novčane naknade uključene u } \\
\text { poreznu osnovicu }\end{array}$ & 0 & 0 & 0 & 0 \\
\hline 5.3. Porezna osnovica & 13.231 & 14.906 & 20.684 & 14.906 \\
\hline $\begin{array}{l}\text { 5.4. Porez na dohodak prije umanjenja } \\
\text { poreza }\end{array}$ & 1.919 & 2.288 & 3.935 & 2.288 \\
\hline 5.5. Umanjenje poreza & 855 & 855 & 855 & 428 \\
\hline $\begin{array}{l}\text { 5.6. Porez na dohodak nakon umanjenja } \\
\text { poreza }\end{array}$ & 1.064 & 1.433 & 3.080 & 1.907 \\
\hline 5.7. Prirez porezu na dohodak & 0 & 0 & 0 & 0 \\
\hline $\begin{array}{l}\text { 5.8. Neto ukupni iznos poreza na } \\
\text { dohodak }\end{array}$ & 1.064 & 1.433 & 3.080 & 1.907 \\
\hline 6. Ukupni porezi i doprinosi posloprimca & 2.970 & 3.976 & 6.258 & 4.450 \\
\hline
\end{tabular}

7. Novčane naknade za obitelj

\begin{tabular}{lrrrr}
\hline 7.1. Za člana obitelji & 0 & 0 & 0 & 0 \\
\hline 7.2. Za djecu & 701 & 637 & 0 & 0 \\
\hline 7.3. Ukupno & 701 & 637 & 0 & 0 \\
\hline 8. Neto dohodak & 15.065 & 19.775 & 22.634 & 18.664 \\
\hline 9. Neto prosječna porezna stopa (u \%) & 6,1 & 6,2 & 10,7 & 8,3 \\
\hline 10. Neto prosječni porezni klin (u \%) & 29,8 & 30,9 & 36,7 & 34,7 \\
\hline
\end{tabular}

Izvor: autoričini izračuni na temelju OECD-a (2014.). 
TABLICA A9.

Oporezivanje dohotka hipotetskih jedinica: samaca (Slovenija, 2013.)

\begin{tabular}{|c|c|c|c|c|}
\hline & 1A-67-NC & 1A-100-NC & 1A-167-NC & 1A-67-2C \\
\hline 1. Bruto plaća (EUR) & 11.740 & 17.611 & 29.351 & 11.740 \\
\hline 2. Doprinosi poslodavca & 1.890 & 2.835 & 4.725 & 1.890 \\
\hline 3. Porez na platnu listu & 0 & 0 & 0 & 0 \\
\hline 4. Doprinosi posloprimca & 2.595 & 3.892 & 6.487 & 2.595 \\
\hline \multicolumn{5}{|l|}{ 5. Porezi na dohodak posloprimca } \\
\hline \multicolumn{5}{|l|}{ 5.1. Standardni odbitci i olakšice } \\
\hline 5.1.1. Osnovni & 4.419 & 3.303 & 3.303 & 4.419 \\
\hline 5.1.2. Za oženjene ili glavu obitelji & 0 & 0 & 0 & 0 \\
\hline 5.1.3. Za djecu & 0 & 0 & 0 & 5.086 \\
\hline 5.1.4. Odbitak za doprinose & 2.595 & 3.892 & 6.487 & 2.595 \\
\hline 5.1.5. Troškovi vezani za rad & 0 & 0 & 0 & 0 \\
\hline 5.1.6. Ukupno & 7.013 & 7.195 & 9.789 & 12.099 \\
\hline 5.2. Novčane naknade uključene u poreznu osnovicu & 0 & 0 & 0 & 0 \\
\hline 5.3. Porezna osnovica & 4.727 & 10.416 & 19.562 & 0 \\
\hline 5.4. Porez na dohodak prije umanjenja poreza & 756 & 1.930 & 4.483 & 0 \\
\hline 5.5. Umanjenje poreza & 0 & 0 & 0 & 0 \\
\hline 5.6. Porez na dohodak nakon umanjenja poreza & 756 & 1.930 & 4.483 & 0 \\
\hline 5.7. Prirez porezu na dohodak & 0 & 0 & 0 & 0 \\
\hline 5.8. Neto ukupni iznos poreza na dohodak & 756 & 1.930 & 4.483 & 0 \\
\hline 6. Ukupni porezi i doprinosi posloprimca & 3.351 & 5.822 & 10.970 & 2.595 \\
\hline \multicolumn{5}{|l|}{ 7. Novčane naknade za obitelj } \\
\hline 7.1. Za člana obitelji & 0 & 0 & 0 & 0 \\
\hline 7.2. Za djecu & 0 & 0 & 0 & 2.716 \\
\hline 7.3. Ukupno & 0 & 0 & 0 & 2.716 \\
\hline 8. Neto dohodak & 8.389 & 11.789 & 18.381 & 11.862 \\
\hline 9. Neto prosječna porezna stopa (u \%) & 6,4 & 11,0 & 15,3 & 0,0 \\
\hline 10. Neto prosječni porezni klin (u \%) & 38,5 & 42,3 & 46,1 & 13,0 \\
\hline
\end{tabular}

Izvor: autoričini izračuni na temelju OECD-a (2014.). 
TABLICA A10.

Oporezivanje dohotka hipotetskih jedinica: parova (Slovenija, 2013.)

\begin{tabular}{|c|c|c|c|c|}
\hline & $2 A-100 / 0-2 C$ & $2 A-100 / 33-2 C$ & $2 A-100 / 67-2 C$ & 2A-100/33-NC \\
\hline 1. Bruto plaća (EUR) & 17.611 & 23.481 & 29.351 & 23.481 \\
\hline 2. Doprinosi poslodavca & 2.835 & 3.780 & 4.725 & 3.780 \\
\hline 3. Porez na platnu listu & 0 & 0 & 0 & 0 \\
\hline 4. Doprinosi posloprimca & 3.892 & 5.189 & 6.487 & 5.189 \\
\hline \multicolumn{5}{|l|}{ 5. Porezi na dohodak posloprimca } \\
\hline \multicolumn{5}{|l|}{ 5.1. Standardni odbitci i olakšice } \\
\hline 5.1.1. Osnovni & 3.303 & 7.876 & 7.721 & 7.876 \\
\hline 5.1.2. Za uzdržavanog člana & 2.437 & 0 & 0 & 0 \\
\hline 5.1.3. Za djecu & 5.086 & 5.086 & 5.086 & 0 \\
\hline 5.1.4. Odbitak za doprinose & 3.892 & 5.189 & 6.487 & 5.189 \\
\hline 5.1.5. Troškovi vezani za rad & 0 & 0 & 0 & 0 \\
\hline 5.1.6. Ukupno & 14.718 & 18.151 & 19.294 & 13.065 \\
\hline $\begin{array}{l}\text { 5.2. Novčane naknade uključene u } \\
\text { poreznu osnovicu }\end{array}$ & 0 & 0 & 0 & 0 \\
\hline 5.3. Porezna osnovica & 2.893 & 5.330 & 10.057 & 10.416 \\
\hline $\begin{array}{l}\text { 5.4. Porez na dohodak prije umanjenja } \\
\text { poreza }\end{array}$ & 463 & 853 & 1.609 & 1.930 \\
\hline 5.5. Umanjenje poreza & 0 & 0 & 0 & 0 \\
\hline $\begin{array}{l}\text { 5.6. Porez na dohodak nakon umanjenja } \\
\text { poreza }\end{array}$ & 463 & 853 & 1.609 & 1.930 \\
\hline 5.7. Prirez porezu na dohodak & 0 & 0 & 0 & 0 \\
\hline $\begin{array}{l}\text { 5.8. Neto ukupni iznos poreza na } \\
\text { dohodak }\end{array}$ & 463 & 853 & 1.609 & 1.930 \\
\hline 6. Ukupni porezi i doprinosi posloprimca & 4.355 & 6.042 & 8.096 & 7.119 \\
\hline \multicolumn{5}{|l|}{ 7. Novčane naknade za obitelj } \\
\hline 7.1. Za člana obitelji & 0 & 0 & 0 & 0 \\
\hline 7.2. Za djecu & 701 & 637 & 0 & 0 \\
\hline 7.3. Ukupno & 701 & 637 & 0 & 0 \\
\hline 8. Neto dohodak & 15.065 & 19.775 & 22.634 & 18.664 \\
\hline 9. Neto prosječna porezna stopa (u \%) & 6,1 & 6,2 & 10,7 & 8,3 \\
\hline 10. Neto prosječni porezni klin (u \%) & 29,8 & 30,9 & 36,7 & 34,7 \\
\hline
\end{tabular}

Izvor: autoričini izračuni na temelju OECD-a (2014.). 